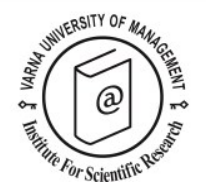

\title{
Factors for the e-business adoption by small tourism firms and the role of shadow economic practices
}

\author{
Zhelyu Vladimirov ${ }^{1}$
}

Received: 26/07/2014 Accepted: 05/11/2014

${ }^{1}$ Sofia University St Kliment Ohridski, 1504, Faculty of Economics and Business Administration 15 Tzar Osvoboditel, Sofia, Bulgaria, Tel.:+359(2)8738123, Fax: +359(2)8702118, Email: jeve@feb.uni-sofia.bg

\begin{abstract}
The goal of this study is to reveal the main factors influencing the e-business adoption by the small tourism firms in Bulgaria with a special attention on the role played by the shadow economic practices in this process. These practices relate to undeclared work, undeclared deals, and sales underreporting by legally registered firms. The research is based on data gathered from 282 small tourism firms' managers through a structured questionnaire. The exploratory factor analysis provided five factors as antecedents to the e-business adoption. These factors reflect the perceptions of environmental pressure, organisational readiness, shadow economic practices in the sector, and managers' attitudes (positive and negative) towards the e-business. The effects of the factors on the e-business adoption are assessed by a multiple regression model, which include also manager experience and firm size as control variables.
\end{abstract}

The findings suggest that environmental pressure, organisational readiness, and positive expectations are more likely to enhance the e-business adoption. The manager experience and the firm size influence positively this adoption too. On the contrary, negative expectations and particularly the perceptions of the spread up of shadow economic practices in the sector were more likely to work against the e-business adoption by small tourism firms.

(C) 2015 Varna University of Management. All rights reserved

Keywords: factors, e-business adoption, shadow economy, small tourism firms, Bulgaria

Citation: Vladimirov, Z. (2015) Factors for the e-business adoption by small tourism firms and the role of shadow economic practices. European Journal of Tourism Research 10, pp. 5-34

\section{Introduction}

During the past ten years the tourism sector experienced a huge rise in online bookings and travel. This was supported by sophisticated networks, based on the new ICT developments. In 2010 , over $50 \%$ of leisure trips, $40 \%$ of business trips, and $30 \%$ of the global travel market each were booked online (WTTC, 2011: 22, 23). While the internet booking by the European travellers in 2013 increased to $76 \%$, compared to $13 \%$ ten years ago, the booking by travel agencies decreased from $65 \%$ to $18 \%$ for the same periods (European Travel Commission [ETC], 2013b). 
The tourism is an important sector of the Bulgarian economy. In 2012 it accounted for $13.6 \%$ of the country GDP, and it was forecast to rise by $1.9 \%$ yearly until 2023 (The World Travel and Tourism Council [WTTC], 2013). At the same time the key markets for Bulgaria as tourism destination (Germany, UK, Russia, France, Romania, and others) demonstrated a significant increase in tourism online sales (ETC, 2013a). The scope of the internet users in Bulgaria also increased - in 2013 more than half of the population (51.2\%) regularly used internet. The travel and hotel reservations in 2013 took a second place $(32.9 \%)$ in online purchases after clothing and sportswear (National Statistical Institute [NSI], 2013). For the 2006-2012 period the volume of online sales of tourism products in Bulgaria increased, although at slow pace - from about $46 \mathrm{~m}$ euro to $64 \mathrm{~m}$ euro. The part of online sales in 2012 , however, barely reached $10 \%$, compared to the whole travel retail sales $(600 \mathrm{~m}$ euro) (Euromonitor Report, 2011). The share of enterprises using e-commerce in 2013 was also small (only $8 \%$ received orders online and $6.8 \%$ purchased online). The research of 249 websites of Bulgarian tourism firms demonstrated that the majority were well presented in terms of the variety of tourism products and services, quality of information, and playfulness. What was missing most often was the lack of full e-business services, including online payment (Vladimirov, 2012:179-180). This situation requires better understanding of the factors, which stimulate the inclusion of the small tourism firms in the online market.

Few innovations have such an immense potential as the e-business for increasing firms' efficiency and sales (Turban et al., 2006; Blake et al., 2006), improvement of internal processes, cost saving, and greater customer satisfaction (Kaynak et al., 2005; Falk, 2005). In spite of the proven advantages, the use of ebusiness in small firms is still insufficient (Beekhuyzen et al., 2005; Eikebrokk \& Olsen, 2007; Chong, 2008). Most often this was explained by small size related shortages such as weaker resources (Riemenschneider et al., 2003), less complex information system management (Ramdani \& Kawalek, 2007: 49), specific cultural, economic and commercial reasons (Liew, 2009: 17), etc.

In the global online touristic market today many small tourism firms (STF) are threatened by disintermediation. It reflects the process of the elimination of intermediaries within the distribution channel by electronic means that enables consumers to transact directly with suppliers and destinations (Buhalis, 2003). Although a partial disintermediation is inevitable, there will be sufficient market share for tour operators and travel agents who can deliver personalised and competitive holiday packages (Buhalis \& Jun, 2011:18-19). To prevent the disintermediation, the retail travel agencies have to become more customeroriented (Bennett \& Lai, 2005). Thus the traditional intermediaries have to shift their role to consumer advisors by utilising internet tools for delivering personalised tourism products. Otherwise they will be unable to compete in the future (Buhalis \& Jun, 2011: 30; Werthner \& Ricci, 2004: 103).

Among the factors influencing the e-business adoption by small tourism firms less attention was given to specific institutional conditions, under which the firms operate. An important institutional dimension, in the emergent and transition economies, is the variety of shadow economic practices. Many STFs in these economies succeed to survive out of the online tourism market. In some cases it is due to specific products, like a religious tourism in Egypt (Abou-Shouk et al., 2012: 206, 208), or other cultural features (Gong, 2009: 92; Tan et al., 2007: 342). In other cases, however, the non-adoption of the e-business might reflect a very specific institutional feature: the opportunity of the small firm manager to keep a business non transparent in order to avoid taxes or paying full social security. This behaviour is facilitated by the weak institutions. To our knowledge, however, there were no researches on the connections between the ebusiness adoption by small tourism firms and the spread up of the shadow economic practices in the sector.

While in less developed countries the informal sector refers to unregistered small businesses, in the developed countries, including the EU 
ones, the informality refers mainly to shadow economic practices such as undeclared work, undeclared transactions, and sales underreporting by legally registered firms. According to Schneider (2012:6) the shadow economy includes all market-based legal production of goods and services that are deliberately concealed from public authorities in order to avoid: 1) payment of income, value added or other taxes; 2) payment of social security contributions; 3) having to meet certain legal labour market standards, such as minimum wages, maximum working hours, safety standards, etc.; and 4) complying with certain administrative obligations, such as completing statistical questionnaires or other administrative forms.

This paper has been guided by the idea that the e-business adoption itself is a distinct, critical, and growing topic in e-business researches. Under its umbrella many research questions can be investigated, "such as adoption factors, adoption barriers, adoption theories, and adoption differences across units, regions, and cultures" (Chen \& Holsapple, 2013:262). Most of researches on the SMEs ebusiness adoption explore the factors (barriers and drivers) that influence SMEs ownermanager adoption decisions. As Gibbs et al. (2007) stated, however, there is a need to develop further an integral theoretical framework for explaining the IT adoption by small firms. Thomas et al. (2011) also underlined the necessity of more empirical researches on the e-business adoption by small tourism firms in different contexts. The paper aims to contribute to the knowledge of the factors influencing the e-business adoption by STF with an accent on the role played by the shadow economic practices on this process. It is based on data of 282 small tourism firms in Bulgaria. The study attempts to answer the following research questions:

1. What are the main factors, which impact positively or negatively the e-business adoption by STF?

2. What is the influence of the perceived shadow economic practices in the sector on the e-business acceptance by STF?
For this purpose an exploratory factor analysis was run, followed by a multiple regression model. The paper is organised as following: next is the literature review, followed by research methodology, results and discussion, and conclusion.

\section{Literature review}

\section{E-commerce and e-business}

The notion of e-business is larger than that of e-commerce (Simpson \& Docherty, 2004) as the latter comprises only "the process of buying and selling products or services using electronic data transmission via the Internet and the www" (Grandon \& Pearson 2004:197). According to many researchers if the ecommerce deals mainly with the transactions of a firm's customers, the e-business enlarges the connectivity of the organization to include suppliers, employees and business partners (Rodgers et al., 2002; Pavic et al., 2007). Wang and Cheung (2004:43) define an e-business as a use of Internet technologies to manage business processes, such as sales and purchase, supply chains, and customer relationships. Zhu and Kraemer (2005:61) consider the e-business as a use of internet for performing and maintaining business activities through the value chain. The most encompassing definition of the e-business is given by the World Tourism Organisation (WTO) (2001:10-11): for the tourism studies the e-business includes the "improved connectivity both externally, through the Internet, and internally, through intranets". The external dimension links tourism suppliers to the customers and their own suppliers, which results in e-marketing, e-commerce, and eprocurement. The internal dimension reveals the organisational transformation, enabling it to work in a fully integrated way through the use of common systems.

\section{Stages of e-business adoption and e-business models}

The stages of e-business adoption overlap to some degree with the development of ebusiness models. The higher the stage of ebusiness adoption, the more sophisticated the e-business model might be (Timmers, 1998:10; Rao et al., 2003:15). This does not mean that the small firms follow always the linear adoption of different component of e-business - 
as a Model of Internet Commerce Adoption (MICA) (Cooper \& Burgess, 2000). Many authors considered that conventional business models were inadequate given the hesitancy of small owner operators towards e-business adoption (Morrison \& King, 2002:107; Levy \& Powell, 2002:508). Taylor and Murphy (2004) contrasted the linear model of e-business adoption by SMEs with the more realistic "PIT" model (Foley \& Ram, 2002). If the linear model suggests that engagement with the e-business technology is sequential and progressive, the nonlinear model demonstrates that firms must cross two digital divides. The first divide involves acquiring basic IT skills and technology, while the second digital divide is the "threshold to e-business proper, and requires advanced technology and IT skills..." (Taylor \& Murphy, 2004:283). Lawson et al. (2003:274) also demonstrated that having a Web presence that encompassed Stage 1 and elements of Stage 2 [of MICA model] could be accomplished alongside existing business practices, while the movement from Stage 2 to Stage 3 appeared to be a hard barrier.

The "business model" usually includes: architecture for the product, service and information flows; description of different business actors and their roles; potential benefits for these actors; description of the sources of revenues (Timmers, 1998:2; Amit \& Zott, 2001:511; Demetriades \& Baltas, 2003:212-213). Timmers (1998:10) classified eleven e-business models on the ground of their innovation and functional integration, while the classification of Rappa (2001) includes nine e-business models based on the firm' value proposition and the way of generating revenue. Nikabadi and Jafarian (2012:88-89, 91) summarized the classification of various ebusiness models and provided a framework for selecting an appropriate e-business model for SMEs.

Brown and Kaewkitipong (2009:213) considered that the travel service sector has a similar structure to conventional retail/ wholesale businesses. Stakeholders include suppliers, intermediaries such as wholesalers, retail travel agencies, technology providers and customers or travellers. This similarity assumes that the tourism sector shares similar e- business models such as: Business to Customer (B2C); Business to Business (B2B); Customer to Customer (C2C); Government to Business (G2B); Business to Business to Customer (B2B2C); Government to Business to Customer (G2B2C) (Wei et al., 2006; Manucci, 2010; Kabir et al., 2012:31-32). According to Soteriades et al. (2004) the most frequently used e-business models in the tourism industry are: brokerage; advertising; infomediary; and etailing. The last one includes: e-store; e-mall (consisting of many e-stores); and e-broker (providing aid to customers who search for products). Most of these e-models have been implemented by the big online travel intermediaries and have been even licensed (Law, 2001). The wholesale travel agencies conduct their business mainly on a $B 2 B$ model (Brown \& Kaewkitipong, 2009:215), while the retail travel agencies work mainly under the B2C model (Wynne et al., 2002; Werthner \& Ricci, 2004:101).

Different tourism organisations choose different levels of e-business. Some firms use only email for communication, whereas others operate almost entirely online. The small tourism companies can move from having a simple web presence (making brokerage and advertising under the B2C model) to value delivery through higher integration of activities (becoming value chain service provider, creating virtual business community, and collaboration platform under different B2B model).

\section{Main theories of e-business adoption}

Hong and Zhu (2006) found that more than ten theories have been applied to study the ebusiness adoption. Parker and Castleman (2009:170) identified the commonly used small firm e-business adoption theories such as: resource-based theory; Porter's generic strategies, industry forces; theory of planned behaviour; technology acceptance model; and Rogers' diffusion of innovation theory. They proposed an additional social network theory (SNT), which posits that social context can influence the motives and behaviours of individuals and organisations (Parker \& Castleman, 2009:175). A comprehensive review of main theories for investigating the IT and e-business adoption by small firms was 
given by Ramdani and Kawalek (2007), Oliveira and Martins (2011) and others.

According to the technology acceptance model (TAM), the adoption of the new information system depends on the users' perceptions and attitudes in terms of perceived usefulness and perceived ease of use (Davis, 1993:475). Subsequently Venkatesh and Davis (2000) proposed a unified theory of acceptance and use of technology, which included additional (mainly moderating) variables (such as experience, age, and subjective norm) (Venkatesh et al., 2003:21; Sun \& Zhang, 2006:54). Other studies, however, reported that attitudes toward technology are influenced also by external factors (Lee et al., 2003). Legris et al. (2003) suggested that the TAM should be integrated into a broader model, which could include variables related to human and social change processes. Šumak et al. (2012:305, 308) considered that few e-business acceptance studies have identified external factors separately or in order to extend the TAM model. For that reason they proposed an extended e-business acceptance model, which include the TOE related factors to the TAM model. Brown and Kaewkitipong (2009:226) found that external factors (e.g. business environment, customers, competitors) are the main drivers of IT adoption by the SMEs.

The e-business implementation can be studied for different units - from an individual consumer to the level of organization, region, or country. Many researchers claimed that at the firm level the TOE framework is the most suitable. This framework was used by Bordonaba-Juste et al. (2012), Chong et al. (2009), Ifinedo (2011), and others. Chen and Holsapple (2013:270) also considered that the TOE framework is appropriate for e-business adoption at the level of organizations, while TAM could be used for both individuals and organizations. According to Ramdani et al. (2013) the TOE model is a robust tool to predict the adoption of enterprise applications by SMEs.

Oliveira and Martins (2011:110) showed that most of studies on the IT acceptance at a firm level were based on Roger's (1995) innovation diffusion theory (IDT); technology, organization, and environment (TOE) framework (Tornatzky
\& Fleischer, 1990); and lacovou et al. (1995) model, or their combinations. Rogers (2003) revealed five segments of adopters of new technology (innovators, early adopters, early majority, late majority, and laggards) in function of the information spill over between users and non-users. lacovou et al. (1995) analysed factors for the IT acceptance such as perceived benefits, organizational readiness, and external pressure. The TOE framework identified three aspects of the firm's context (technological, organizational, and environmental), which impact the adoption. Below we present some of these factors in detail (see also Appendix 3).

\section{Technological context}

Rogers (2003:229) defines relative advantage of the new technology adoption as "the degree to which an innovation is perceived as being better than the idea it supersedes". This understanding is close to the perceived usefulness and benefits, which influence the new technologies adoption and use (Gunasekaran \& Ngai, 2005; Ifinedo, 2011).

Morrison and King (2002:106-107) observed that "the adoption of ecommerce by small tourism owner operators is shaped by factors concerned with attitudes, motivations and business performance". Fishbein and Ajzen (1975:216) viewed the attitude as "a learned predisposition to respond favourably or unfavourably toward something". The attitudes have a strong influence on both the intention to use (McKechnie et al., 2006) and the actual use of the new technology (Davis et al. 1989). Managers' positive perceptions influence their attitudes toward e-commerce adoption, while the negative ones prevent this adoption (Saffu \& Walker, 2008; Simmons et al., 2008; Pham et al., 2011). Other studies viewed the strategic value of e-commerce adoption as a difference between perceived benefits and perceived costs (Kwun et al., 2010).

The positive attitudes are related to the expected benefits to be derived from the ebusiness adoption and use (Baldwin et al., 2004; Grandon \& Pearson, 2004; Al-Qirim, 2007; Chibelushi \& Costello, 2009). These benefits are categorized as strategic, informational and operational (Boateng et al., 2008:564). Strategic benefits are associated 
with attracting new customers and increased market shares (Raymond, 2001; MacGregor \& Vrazalic, 2004); operational benefits refer to different cost reductions (Fillis \& Wagner, 2005; Teo et al., 2009); and informational benefits are associated with improving marketing and communication with partners and customers (Poon \& Swatman, 1999).

The negative attitudes come from the expected disadvantages and barriers to new technologies such as high cost, limited funds, and non-immediate return of investments (Migiro \& Ocholla, 2005; Johnson, 2010), lack of trust in online transactions (Lawson et al., 2003), loss of personal relations with clients and suppliers (Ritchie \& Brindley, 2001), lack of online capacity of suppliers (Galloway, 2006), and insufficient IT knowledge and skills (Riemenschneider et al., 2003; Simpson \& Docherty, 2004). These attitudes may be related to the spread up of shadow economic practices, which remains an under researched question. If the positive attitudes are considered as enablers to the e-business adoption (Levy et al., 2005; Hsu et al., 2006), the negatives ones are viewed as barriers to this adoption (Stockdale \& Standing, 2006).

\section{Organisational readiness}

The organisational characteristics address firm size, structure, and human capital. The researches have shown a positive relationship between the firm size and the level of the IT use, which is explained by greater resources (Wang \& Cheung, 2004; Stockdale \& Standing, 2006; Lun \& Quaddus, 2011). There were studies, however, which did not confirm the significance of these relations (Daniel et al., 2002; Lefebvre et al., 2005), or revealed negative correlations with firm size in the case of e-business adoption (Lucchetti \& Sterlacchini, 2004; Karakaya \& Shea, 2008). According to Parker and Castleman (2007) these discrepancies may be due to the treatment of small and medium enterprises and e-business applications homogeneously instead of diverse and complex entities.

The human capital refers to the employees' IT knowledge and skills. More educated and young staff can facilitate the use of IT (O'Donnell et al., 2001; Fabiani et al., 2005), while it would be more difficult for less educated and older employees, who have to learn yet new technologies. The support of the top management is also crucial (Caldeira \& Ward, 2002; To \& Ngai, 2007). Eikebrokk and Olsen (2007:369) found that competency in IT management is positively associated with ebusiness success. Other researchers have identified inherent to the micro-firms difficulties to implement IT such as little or no staff training and a lack of managers' awareness of the potential benefits (Wolcott et al., 2008; Jones et al., 2011).

\section{Environmental context}

\section{Economic environment}

In general, the environmental context includes level of competition (Baldwin et al., 2004; Sparling et al., 2007), specific sector (Love et al., 2005), pressure of both customers and suppliers (Merhtens et al., 2001; Daniel et al., 2002; Levy et al., 2005; Wu et al., 2006; Lee \& Kim, 2007; Shih, 2008), government initiatives (Zhu \& Thatcher, 2010) and, of particular relevance to this paper, the institutional environment (Kshetri, 2010). Some authors found that the excessive competition impact negatively the e-commerce adoption by SME (Ludivine, 2009; Jeon et al., 2006). The service sector, including tourism, depends stronger on the information systems because of the greater significance of data processing (Oliveira \& Martins, 2010). The specificity of products also play an important role - intangible products with a high rate of information contents like tourism ones are more convenient to sell online (OECD, 2004:34; Dinlersoz \& Pereira, 2007:542). Firms operating on the international markets use more intensively IT because of the necessity of faster communication and coordination (Bayo-Moriones \& Lera-López, 2007:353, 354). The e-business adoption depends on the suppliers' readiness too (Raymond, 2001:414). As the internet became the most influential information sources for travel, the pressure on behalf customers increased significantly (Niininen et al., 2007:266).

Institutional environment

Government support and institutional protection of online transactions stimulate also the ebusiness diffusion (OECD, 2004:35). The 
research showed that the innovations adoption by SMEs was significantly and negatively linked to the high levels of taxes, regulations, and bribes (Anderson et al., 2004:110) Non adoption of the e-business might be a way to avoid these burdens (Humphrey et al., 2003:34). In the institutionally weak economies some entrepreneurs are more prone to resort to shadow economic practices instead of embracing innovations. Kshetri (2010:164) showed that around $35-40 \%$ of business transactions in some Asian countries are conducted in cash, and the use of credit cards is too small to allow the growth of e-commerce.

The Visa Europe et al. (2013:14-15) reported that the scale of the shadow economy in Europe ranged from 8-10 percent of GDP in Switzerland, Austria, the Netherlands and the UK, through to nearly 30 percent of GDP in Bulgaria, Croatia, Lithuania and Estonia. This report revealed that undeclared work accounted for two thirds of the shadow economy while another third was a result of sales under-reporting. The report suggested that there was a clear correlation between the size of the shadow economy and the number of electronic payments. In countries where electronic payments were widely used, such as the UK and the Netherlands, the size of the shadow economy was significantly smaller compared to countries with less electronic payments, such as Bulgaria and Romania.

According to the European Parliament report (2013), the shadow economy was particularly presented in the services sector. The OECD tax authorities outlined that hospitality and tourism shared the second and third place among sectors or taxpayer groups of most concern (OECD, 2012:23). A good part of the tax gap in these sectors is caused by undeclared work and undeclared sales, reflecting the large number of cash-based transactions in these sectors (European Parliament, 2013:39).

Previous researchers used a combination of theories to investigate the adoption of different IT applications such as ERP (Pan \& Jang, 2008), e-commerce (Bao \& Sun, 2010), and ebusiness (Lin \& Lin, 2008). Most of the studies used multiple or logistic regression models with a few exceptions, where the structural equation modelling (SEM) was applied. For instance Wang and Cheung (2004:45) explained the e-business acceptance in tourism by external competitive pressure, innovation orientation, financial slack, and IT resources. Hsu et al. (2006:16) included four constructs in their model (perceived benefits, organizational readiness, external pressure, and environment), which impact the e-business adoption. Bayo-Moriones and Lera-López (2007:353-354) suggested five factors influencing the IT adoption: environment; firm characteristics; human capital; competitive strategies; and internal organisation. Lin and Lin $(2008: 137,142)$ tested TOE factors (IS infrastructure and expertise; organisational compatibility and expected benefits; competitive pressure and partner readiness) on the e-business diffusion. Salwani et al. (2009:173) investigated relationships among components of TOE model on the e-business usage. Oliveira and Martins (2010:1339) proposed three groups of factors (perceived benefits, technology and organizational readiness, and environmental pressure, controlling for country and industry sector) to explain the e-business adoption by the EU firms in two sectors - telecommunications and tourism. Abou-Shouk et al. (2013) revealed the positive effects of external drivers and perceived benefits and negative effects of internal and external barriers on small tourism agents in Egypt to adopt the e-commerce.

Summing up, most of the researches on the IT and e-business adoption by small firms fell under the following headings: (1) external drivers and barriers for acceptance; (2) internal forces and inhibitors; and (3) manager's attitudes towards new technology. Similar types of drivers and barriers were identified by MacGregor and Vrazalic (2004:14), Fillis and Wagner (2005:617), Mohamad and Ismail (2009:5), Beckinsale et al. (2010:195, 196), Chang et al. (2010:88), Oliveira and Martins (2011:117), Ghobakhloo et al. (2011), Cosgun and Dogerlioglu (2012:1668), Peixin and Xie (2012:23), Bordonaba-Juste et al. (2012:536), Jabeur et al. (2013:5), and others.

As it was said, however, less attention was given to such institutional dimension as the 
level of shadow economy in the tourism sector and its influence on the e-business adoption. Except for some publications in the everyday press, there were no systemic researches on the role played by the shadow economic practices in respect to the new IT acceptance. The present paper aims at filling this gap. It is based on the combination of TOE framework, IDT, and lacovou et al. (1995) model, but it adds an additional institutional characteristic namely the shadow economy. This dimension is particularly important to the understanding of small firms' behaviour in emergent and transition economies (Welter \& Smallbone 2011).

Following the results of the literature review, the next hypotheses are proposed:

$\mathrm{H} 1$. Environmental pressure $(\mathrm{H} 1 \mathrm{a})$, organisational readiness $(\mathrm{H} 1 \mathrm{~b})$, and positive managers' attitudes ( $\mathrm{H} 1 \mathrm{c})$ will influence positively the e-business adoption by small tourism firms.

H2. The perceived spread up of the shadow economic practices $(\mathrm{H} 2 \mathrm{a})$ and negative managers' attitudes ( $(\mathrm{H} 2 \mathrm{~b})$ will impact negatively the e-business adoption.

H3. The positive managers' attitudes are more likely to be correlated negatively with the perceptions of the shadow economy ( $\mathrm{H} 3 \mathrm{a}$ ) and positively with other factors (organizational readiness, industry environment, manager experience, and firm size) (H3b);

$\mathrm{H} 4$. The negative managers' attitudes are more likely to be correlated positively with the perceptions of shadow economy $(\mathrm{H} 4 \mathrm{a})$ and negatively with other factors (organizational readiness, industry environment, manager experience, and firm size $(\mathrm{H} 4 \mathrm{~b})$

$\mathrm{H} 5$. The firm size $(\mathrm{H} 5 \mathrm{a})$ and the manager IT experience $(\mathrm{H} 5 \mathrm{~b})$ will enhance the e-business adoption.

\section{Research methodology}

In this study we use parts of a larger survey instrument, which was developed to identify the situation with the e-tourism development in Bulgaria. The questions in the survey addressed some important e-business adoption issues, including the effects of industry environment and shadow economic practices in the tourism sector, organisational readiness for online communication and transactions, expected benefits and disadvantages from the e-business implementation, relations with customers and suppliers, and others. Before the survey we conducted 30 interviews with small tourism firms' managers (Appendix 4). These interviews had a twofold purpose: to check the questionnaire and to receive in depth information through open questions, which could help the data interpretation (Mohamad \& Ismail, 2009). After the pre-test some questions were slightly improved. In this paper we rely on the responses of 7 questions with 28 items, related to the above research questions. All of the individual variables were scored on fivepoint Likert scales, except for the firm's size, which was measured by the logarithm of the number of employees. The ratio between variables and cases was around 10:1, which is an acceptable level (Hair et al., 2010:102).

The sample covered 282 Bulgarian small tourism organizations, of which $36(12.8 \%)$ were only tour operators (TO); other 36 $(12.8 \%)$ - only travel agents (TA); $67(23.8 \%)$ functioned as both tour operators and travel agents; 107 (37.9\%) were hotels; $21(7.4 \%)$ travel companies; and 15 (5.3\%) - others. According to the national Law of Tourism, tour operators can organise different travels and holidays, while travel agents can only sell and resell these products. As of 23.08.2013 the number of registered tourism agencies and tour operators was 2660; the number of hotels and

Table 1. Population and sample characteristics

\begin{tabular}{|c|c|c|c|c|c|c|c|c|c|c|}
\hline & \multicolumn{2}{|c|}{$\begin{array}{l}\text { Tour } \\
\text { operators }\end{array}$} & \multicolumn{2}{|c|}{ Travel agents } & \multicolumn{2}{|c|}{$\begin{array}{l}\text { Tour operators and travel } \\
\text { agents }\end{array}$} & \multicolumn{2}{|l|}{ Hotels } & \multicolumn{2}{|c|}{$\begin{array}{l}\text { Travel } \\
\text { companies }\end{array}$} \\
\hline & number & $\%$ & number & $\%$ & number & $\%$ & number & $\%$ & number & $\%$ \\
\hline Population & 561 & 100 & 1082 & 100 & 1017 & 100 & 1650 & 100 & 212 & 100 \\
\hline Sample & 36 & 6.41 & 36 & 3.33 & 67 & 6.59 & 107 & 6.48 & 21 & 9.90 \\
\hline
\end{tabular}

Sources: http://tourism.egov.bg/registrs/TORegister.aspx;

http://www.rta.government.bg/index.php?page=scategories\&scategory=registry;

http://www.rta.government.bg/images/Image/registri/spravka_riskovi_kategorii_FI NAL \%202013.pdf 
other places for accommodation similar to hotels - 1650; and the number of travel companies - 222. In light of these populations the sample is not well representative (Table 1).

Vateva (2010) reported, however, that in 2010 more than $25 \%$ of the TO and TA had expired insurances, but still continued to work. The register of the TO and TA in 2013 showed that about one third of these firms had expired insurances too (National Tourism Register http://tourism.egov.bg/registers/TORegister.asp $x)$. The field data were gathered by a professional agency from managers of registered firms with valid insurances, which makes the sample better representative for those firms. It does not mean, however, that these firms can't apply shadow economic practices. The simple random sampling with replacement in each category was used. The prevalence of TO and TA ( $49 \%$ of all) was due to the fact that these firms prevailed in the population, as well as because they are most treated by the disintermediation (Buhalis \& Licata, 2002). The data were processed on SPSS 20.

To answer the above research questions, first, an exploratory factor analysis was run to delineate the significant factors for the ebusiness adoption by small firms. Second, a multiple regression model was applied to identify the impacts of different factors and two control variables (manager IT experience and firm size) on the e-business acceptance.

The response e-business adoption is evaluated by four aspects - availability of online reservation and payment systems, and backend integration systems such as Supply Chain Management (SCM), Customer Management System (CMS), and Enterprise Resource Planning (ERP). These aspects are based on Zhu and Kraemer (2005) classification of ebusiness capabilities as front-end functionalities and back-end integration. The first ones represent the characteristics of the firm's website (Salwani et al., 2009), while the back-end integration refer to managing relations with customers, suppliers, and internal processes (Turban et al., 2006). These aspects reflect different stages of the adoption - from a common website development to the opportunity of full online transactions and backend integration (Doolin et al., 2002:558; Peng et al., 2005:478; Abou-Shouk et al., 2013:256257).

\section{Results and discussion}

\section{Descriptive statistics}

In respect to the size, $46 \%$ of companies were micro-enterprises (with less than 10 employees); 43\% - small (between 10 and 50 employees); and $11 \%$ - medium sized (between 50 and 250 employees). The microenterprises took a greater part of the sampled firms, because this type of firms is more likely to be included in the shadow economic practices (European Parliament, 2013:39). The average companies' age was 11.25 years with the prevailing share of those aged 6-10 years $(35 \%)$. In about half of the firms the average employees' age was 31-40 years, and in 39\% between 20-30 years, which revealed the predominantly young staff in these firms. The greatest share of firms practiced both inbound and outbound tourism (39\%); $13 \%$ of total specialized only in inbound tourism; another $13 \%$ specialized only in outbound travels; and $35 \%$ were oriented mainly to the internal market. The biggest part of the interviewed managers had a higher education - $59 \%$ were with master degree; $31 \%$ with bachelor degree; $3 \%$ were doctors, and only $7 \%$ had a secondary education. Almost $42 \%$ of managers had a significant experience with IT, and another $12 \%$ were experienced with the newest IT applications (in total 54\%) (Table 2).

\section{Results of the exploratory factor analysis}

We run an exploratory factor analysis (EFA) with a Varimax rotation, and a cut point of 0.35 , which was appropriate for the sample size (Hair et al., 2010:117). The correlation matrix shows that there are sufficient numbers of correlations greater than 0.30, which allows for running the factor analysis (Appendix 1, Table 1). The determinant value is 0.0000244 which implies that there is no linear dependence in the correlation matrix. The anti-image matrix of correlations reveals that there is only one partial correlation greater than 0.5 and less than 0.7 as recommended level by Hair et al. (2010:103), and the measures of sampling adequacy for individual variables range from 0.778 to 0.928 , e.g. greater than minimum 
Factors for the e-business adoption by small tourism firms and the role of shadow economic practices.

recommended level of 0.5 by Hair et al. (2010:103) (Appendix 1, Table 2). The KMO measure of sampling adequacy is 0.881 , DF = 231, Approx. Chi-Square $=2897.707$, and Sig. $=0.000$.

The rotation provided five factors. Because of low and controversial loadings six items were excluded. The convergent validity of the remaining items was verified by analysing the factor loadings and their significance. The communalities of all individual variables are above 0.6. All item-to-factor loadings are greater than 0.7 , which demonstrates a high

Table 2. Descriptive statistics (number and \%)

\begin{tabular}{|c|c|c|c|c|}
\hline \multicolumn{5}{|l|}{ Firm size } \\
\hline Micro- & Small & Medium & \multirow{2}{*}{\multicolumn{2}{|c|}{ Total }} \\
\hline $130(46.1 \%)$ & $121(42.9 \%)$ & $31(11.0 \%)$ & & \\
\hline \multicolumn{5}{|c|}{ Employees' average age } \\
\hline $20-30$ years & $31-40$ years & $41-50$ years & \multicolumn{2}{|c|}{ More than 50} \\
\hline $110(39.0 \%)$ & $138(48.9 \%)$ & $28(9.9 \%)$ & \multicolumn{2}{|c|}{$6(2.1 \%)$} \\
\hline \multicolumn{5}{|l|}{ Firm age } \\
\hline Up to 5 year & $6-10$ year & $11-15$ years & $16-20$ & $>20$ \\
\hline $64(22.7 \%)$ & $99(35.1 \%)$ & $59(20.9 \%)$ & $42(14.9$ & $18(6.4 \%)$ \\
\hline \multicolumn{5}{|c|}{ Firm orientation (type of tourism) } \\
\hline $\begin{array}{l}\text { Inbound and } \\
110(39.0 \%)\end{array}$ & $\begin{array}{l}\text { Ind Only inbound } \\
37(13.1 \%)\end{array}$ & $\begin{array}{l}\text { Only outbound } \\
37(13.1 \%)\end{array}$ & \multicolumn{2}{|c|}{$\begin{array}{l}\text { Only internal market } \\
98(34.8 \%)\end{array}$} \\
\hline \multicolumn{5}{|c|}{ Manager education } \\
\hline Secondary & Bachelor degree & Master degree & \multicolumn{2}{|c|}{ Doctoral degree } \\
\hline $19(6.7 \%)$ & $88(31.2 \%)$ & $166(58.9 \%)$ & \multicolumn{2}{|c|}{$9(3.2 \%)$} \\
\hline \multicolumn{5}{|c|}{ Manager IT experience } \\
\hline $\begin{array}{l}\text { Lack of } \\
\text { experience }\end{array}$ & $\begin{array}{l}\text { Insignificant } \\
\text { experience }\end{array}$ & Some experience & $\begin{array}{l}\text { Significant } \\
\text { experience }\end{array}$ & $\begin{array}{l}\text { Significant with the newest } \\
\text { applications }\end{array}$ \\
\hline $9(3.3 \%)$ & $35(12.3 \%)$ & $88(31.2 \%)$ & $117(41.6 \%)$ & $33(11.6 \%)$ \\
\hline
\end{tabular}

Table 3. Rotated component matrix*

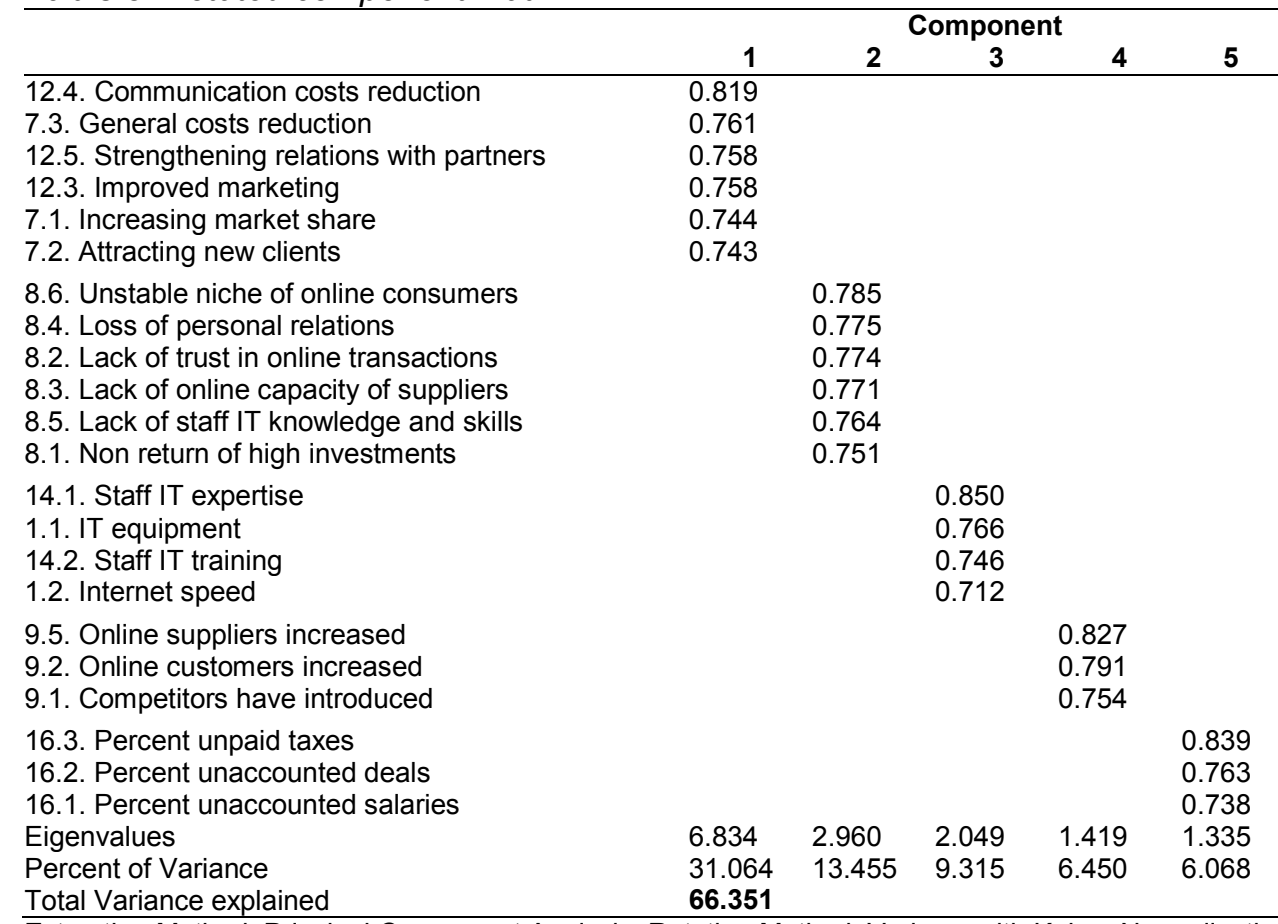

Extraction Method: Principal Component Analysis. Rotation Method: Varimax with Kaiser Normalization ${ }^{*}$ Rotation converged in 5 iterations 
Table 4. Survey items, measurement properties, items loadings, communalities, and Cronbach's Alpha

\begin{tabular}{|c|c|c|c|c|c|}
\hline Constructs and Items & Mean & S.D. & $\begin{array}{l}\text { Items } \\
\text { loadings }\end{array}$ & $\begin{array}{l}\text { Commu- } \\
\text { nalities }\end{array}$ & $\begin{array}{l}\text { Cronbach's } \\
\text { Alpha }\end{array}$ \\
\hline 1. Expected advantages and benefits ${ }^{a}$ & 0.6904 & 0.16271 & & & 0.878 \\
\hline 7.1. Increasing market share & 3.51 & 0.981 & 0.744 & 0.618 & \\
\hline 7.2. Attracting new clients & 3.43 & 0.997 & 0.743 & 0.603 & \\
\hline 7.3. General cost reduction & 3.48 & 1.058 & 0.761 & 0.630 & \\
\hline 12.3. Improved marketing & 3.42 & 1.038 & 0.758 & 0.638 & \\
\hline 12.4. Communication costs reduction & 3.41 & 1.064 & 0.819 & 0.688 & \\
\hline 12.5. Strengthening relations with partners & 3.46 & 1.054 & 0.758 & 0.606 & \\
\hline 2. Expected disadvantages and barriers ${ }^{a}$ & 0.5286 & 0.16355 & & & 0.877 \\
\hline 8.1. Non return of high investments & 2.77 & 0.968 & 0.751 & 0.638 & \\
\hline 8.2. Lack of trust in online transactions & 2.51 & 0.970 & 0.774 & 0.626 & \\
\hline 8.3. Lack of online capacity of suppliers & 2.67 & 1.016 & 0.771 & 0.658 & \\
\hline 8.4. Loss of personal relations & 2.69 & 1.126 & 0.775 & 0.658 & \\
\hline 8.5. Lack of staff IT knowledge and skills & 2.61 & 1.082 & 0.764 & 0.601 & \\
\hline 8.6. Unstable niche of online consumers & 2.60 & 1.060 & 0.785 & 0.631 & \\
\hline 3. Organisational readiness ${ }^{a}$ & 0.7018 & 0.16872 & & & 0.820 \\
\hline 1.1. IT equipment & 3.46 & 0.980 & 0.766 & 0.686 & \\
\hline 1.2. Internet speed & 3.51 & 1.120 & 0.712 & 0.602 & \\
\hline 14.1. Staff IT expertise & 3.48 & 1.048 & 0.850 & 0.771 & \\
\hline 14.2. Staff IT training & 3.59 & 1.034 & 0.746 & 0.606 & \\
\hline 4. Industry environment ${ }^{a}$ & 0.6532 & 0.17819 & & & 0.837 \\
\hline 9.1. Competitors have introduced & 3.27 & 0.957 & 0.754 & 0.736 & \\
\hline 9.2. Online customers increased & 3.26 & 1.001 & 0.791 & 0.725 & \\
\hline 9.5. Online suppliers increased & 3.27 & 1.113 & 0.827 & 0.796 & \\
\hline 5. Shadow economic practices ${ }^{a}$ & 0.4955 & 0.17513 & & & 0.782 \\
\hline 16.1. Percent unaccounted salaries & 2.44 & 1.022 & 0.738 & 0.648 & \\
\hline 16.2. Percent unaccounted deals & 2.50 & 1.071 & 0.763 & 0.686 & \\
\hline 16.3. Percent unpaid taxes & 2.49 & 1.055 & 0.839 & 0.748 & \\
\hline 6. Experience manager ${ }^{a}$ & 3.27 & 1.147 & - & - & - \\
\hline 7. Firm size & 2.6465 & 1.24882 & - & - & - \\
\hline 8. E-business adoption ${ }^{a}$ & 0.6126 & 0.20473 & & & 0.883 \\
\hline 2.1. Online reservation system & 3.05 & 1.169 & & & \\
\hline 2.2. Online payment system & 3.07 & 1.199 & & & \\
\hline 2.3. SCM and CRM & 3.15 & 1.208 & & & \\
\hline 2.4. ERP system & 2.98 & 1.185 & & & \\
\hline
\end{tabular}

items dimensionality (Hair et al., 2010:117). The total variance explained is $66,351 \%$. The first factor does not account for the majority of the variance $(31.064 \%)$, which suggests that common method bias is not of great concern (Table 3).

The instrument's reliability was evaluated with Cronbach's alpha. All factors have alpha values above recommended value of 0.7 (Hair et al., 2010:125) - from 0.782 for the fifth factor to 0.878 for the first factor, which indicates an acceptable consistency of the measures. Survey items, measurement properties, items loadings, communalities, and Cronbach's Alpha are given in Table 4 .
The content validity of the extracted factors is presented below. We named the first factor EXPECTED ADVANTAGES and BENEFITS from the e-business adoption. In line with previous researches this factor reveals managers' expectations about decreasing communication and other costs (Wang \& Cheung, 2004; Fillis \& Wagner, 2005), strengthening relations with business partners (Poon \& Swatman, 1999; Pease \& Rowe, 2005), improving marketing (Scupola, 2003), attracting new clients and increasing market share (Raymond, 2001). These expectations were positively related to the adoption of computers (Legris et al., 2003), e-commerce (Chang et al., 2010), and e-business (Hsu et al., 2006). 
Factors for the e-business adoption by small tourism firms and the role of shadow economic practices.

Parallel to the perceived advantages and benefits, many small tourism firms' managers feel some DISADVANTAGES and OBSTACLES of the e-business, which formed the second factor. As the literature review showed, the negative attitudes were related most often to the lack of trust in online transactions, unstable niche of online customers, loss of personal relations, lack of online capacity of suppliers, insufficient staff IT expertise, and fear of none return of IT investments. These expectations were supposed to impact negatively the e-business adoption (Stockdale \& Standing, 2006:385; Migiro \& Ocholla, 2005:283; Oliveira \& Martins, 2010:47).

The ORGANISATIONAL READINESS in terms of firm's IT infrastructure and human capital represents the third factor. It contains the level of the IT equipment and human resources such as staff IT expertise and training in new technology. The literature review revealed that the advanced IT infrastructure and human resources practices influence positively the ebusiness adoption (Morrison \& King, 2002; To \& Ngai, 2007; Oreku et al., 2009; Chong et al., 2009).

The fourth factor reflects three facets of the INDUSTRY ENVIRONMENT PRESSURE on behalf of more advanced competitors, and an increased share of online customers and suppliers. Previous studies identified this factor as one of the main drivers towards the ebusiness adoption (Baldwin et al., 2004; Niininen et al., 2007).

The fifth factor covers the SHADOW ECONOMIC PRACTICES in the tourism sector, as it reflects the perceived level of none accounting deals and wages, and unpaid due taxes. If the institutional improvements lead to a higher degree of e-business adoption, the opposite situation is a major barrier to such adoption (Lu et al., 2002; Lawson et al., 2003; Stockdale \& Standing, 2006). That is why this factor is assumed to influence negatively the ebusiness acceptance. There were, however, no researches on the relationships between the level of shadow economy and the e-business adoption in the tourism sector.
The assessment of the factors' items shows that they correspond sufficiently to the conceptual definition of the respective factors, which attests an acceptable content validity. These factors were used in a multiple regression model together with two control variables, reflecting the firm size and the manager IT experience. The FIRM SIZE was measured by the logarithm of the number of employees. It is among the most studied factors in the new technology adoption literature, as the company size reflects available resources, past experience, and decision dexterity (Wang \& Cheung, 2004:48; Zhu \& Kraemer, 2005:68). The MANAGER'S IT EXPERIENCE was measured by five-point scale (from 1 - lowest to 5 - highest). Along with managerial beliefs about the e-business benefits and barriers, the manager's IT knowledge and skills play an important role on the decision of the e-business adoption (Stockdale \& Standing, 2006:384).

For the purpose of a regression models, each factor was transformed into a new single composite measure (summated scale), representing a ratio between the sum of scores and the maximum sum of scores of the constitutive variables loaded on this factor (Hair et al., 2010:124). The same procedure was applied to the response, which allowed for the identification of cases with lower, middle, and higher level of the e-business adoption. The cases which score below 0.40 were considered to belong to the lowest and rather lower level of adopters; the cases with scores between 0.40 and 0.60 - to the middle level; and the cases which score above 0.60 - to the rather higher and highest level of adopters. In total $20.2 \%$ of the firms were classified as lowest and rather lower level adopters; other $34.1 \%$ as middle level adopter; and the remaining $45.7 \%$ as rather higher and highest level adopters. Few years ago these ratios would be considered as quite good, but nowadays, when the competitiveness depends on the speed of the adoption of e-business innovations, they seem unsatisfactory.

\section{Results of the multiple regression model}

A multiple linear regression analysis was conducted in order to reveal the most important factors influencing the e-business adoption by 
the small tourism firms. The ratio of cases to independent variables was around 40:1, e.g. higher than the required ratio between 15 and 20 (Hair et al., 2010:176). The values of Cronbach's alpha for scales of the variables, the number of items, means, and SD of variables are given in Table 5.

The correlation matrix indicated that there is only one squared correlation above $0.6(0.654)$, which was the squared correlation between the response e-business adoption and the factor industry environment (Table 6).

This suggested that there are no serious problems with multicollinearity (Hair et al., 2010:204). The analysis revealed that the residuals do not exhibit any nonlinear patterns, which satisfies the requirements of linearity and homoscedasticity of the overall variation. The

Table 5. Number of items, Cronbach's alpha, means, and SDs

\begin{tabular}{lllll}
\hline Predictors & No of Items & Cronbach's $\boldsymbol{\alpha}$ & Mean & S.D. \\
\hline 1. Expected advantages and benefits & 6 & 0.878 & $0.6904^{\mathrm{a}}$ & 0.16271 \\
2. Expected disadvantages and barriers & 6 & 0.877 & $0.5286^{\mathrm{a}}$ & 0.16355 \\
3. Organisational readiness & 4 & 0.820 & $0.7018^{\mathrm{a}}$ & 0.16872 \\
4. Industry environment & 3 & 0.837 & $0.6532^{\mathrm{a}}$ & 0.17819 \\
5. Informal economy & 3 & 0.782 & $0.4955^{\mathrm{a}}$ & 0.17513 \\
6. Manager experience & - & - & $3.27^{\mathrm{a}}$ & 1.147 \\
7. Firm size & - & - & $2.6465^{\mathrm{b}}$ & 1.24882 \\
Response & & & & \\
8. E-business adoption & 4 & 0.883 & $0.6126^{\mathrm{a}}$ & 0.20473 \\
\hline
\end{tabular}

${ }^{\text {a }}$ 5-points scale (1 - lowest; 5 - highest)

${ }^{b} \mathrm{Ln}$ of the number of employees

Table 6. Factors correlation matrix

\begin{tabular}{|c|c|c|c|c|c|c|c|c|}
\hline & 8 & 1 & 2 & 3 & 4 & 5 & 6 & 7 \\
\hline 8. E-business adoption & 1.000 & 0.552 & -0.430 & 0.563 & 0.654 & -0.535 & 0.530 & 0.402 \\
\hline 1. Expected advantages and benefits & & 1.000 & -0.213 & 0.324 & 0.419 & -0.345 & 0.291 & 0.177 \\
\hline 2. Expected disadvantages and barriers & & & 1.000 & -0.263 & -0.360 & 0.322 & -0.257 & -0.179 \\
\hline 3. Organizational readiness & & & & 1.000 & 0.421 & -0.385 & 0.441 & 0.261 \\
\hline 4. Industry environment & & & & & 1.000 & -0.386 & 0.365 & 0.293 \\
\hline 5. Informal economy & & & & & & 1.000 & -0.318 & -0.214 \\
\hline 6. Experience manager & & & & & & & 1.000 & 0.403 \\
\hline 7. Firm size & & & & & & & & 1.000 \\
\hline
\end{tabular}

Table 7. Multiple regression results

\begin{tabular}{|c|c|c|}
\hline Model & $\begin{array}{l}\text { Standardized } \\
\text { coefficients }\end{array}$ & $\mathbf{t}$ \\
\hline \multicolumn{3}{|l|}{ Constant } \\
\hline 1. Expected advantages and benefits & 0.227 & 1.284 \\
\hline 2. Expected disadvantages and barriers & -0.118 & $5.820^{* * *}$ \\
\hline 3. Organisational readiness & 0.177 & $-3.121^{* *}$ \\
\hline 4. Industry environment & 0.289 & $4.279^{* * *}$ \\
\hline 5. Informal economy & -0.167 & $6,801^{* * *}$ \\
\hline 6. Manager experience & 0.152 & $-4.176^{\star \star *}$ \\
\hline 7. Firm size & 0.113 & $3.670^{* * *}$ \\
\hline Adjusted R-square & 0.672 & $2.985^{\star *}$ \\
\hline F-statistics & $83.148^{* \star *}$ & \\
\hline
\end{tabular}

Notes: * $p$-value is significant at the 0.05 level; ${ }^{* *} p$-value is significant at the 0.01 level;

${ }^{* * *} p$-value is significant at the 0.001 level

Dependent Variable: D8. E-business adoption 
confidence interval does not include zero (Hair et al., 2010:193); the tolerance values are moderately high, and the VIF of the independent variables are relatively small respectively. The model is statistically significant and it explains about $67 \%$ of the variance in the response $(\mathrm{R}$-square $=0.680$; adjusted $\mathrm{R}$-square $=0.672 ; \mathrm{F}=83.148, \mathrm{DF}=7$, $\mathrm{p}<0.000, N=282$ ). The regression analysis confirmed the positive impact on the ebusiness adoption of five factors and the negative impact of the remaining two factors (Table 7).

Unsurprisingly, the results of the regression model suggests that the most important factor for the e-business adoption by small tourism firms is the industry environmental pressure on behalf of competitors, customers, and suppliers $(\mathrm{H} 1 \mathrm{a})$. This factor was considered as an important external driver for the e-business acceptance by other researches too (Merhtens et al., 2001; Lewis \& Cockrill, 2002; Lee \& Kim, 2007; Shih, 2008; Chong et al., 2009; Pavlou and El Sawy, 2010).

The managers' positive attitudes in terms of expected advantages and benefits from the ebusiness adoption rank as a second important factor $(\mathrm{H} 1 \mathrm{c})$. The impact of these attitudes (to attract new clients, increase market share, and diminish communication and other costs) on the e-business adoption is in line with the results received by Damanpour (1991), Mehrtens et al. (2001), OECD (2004), Hsu et al. (2006), Bao and Sun (2010), and others. Particularly in small firms the e-business adoption is influenced strongly by manager's perceptions towards IT innovation (MacGregor \& Vrazalic, 2004; Fillis \& Wagner, 2005; Wilson et al., 2008; Chong et al., 2009; Oliveira \& Martins, 2011).

The third important factor for the new technology adoption is the organisational readiness, which is presented by the firm IT infrastructure and the employees IT expertise (H1b). According to Morrison and King (2002), not well developed ICT infrastructure was an important reason, which impedes the inclusion of the Australian small tourism firms into the emarket. The slow speed of internet will not motivate small business to adopt e-commerce too (Pikkarainen et al., 2004; Oreku et al., 2009). Lu et al. (2002: 206) observed that in Chinese SME "the main technical barrier is the lack of E-commerce application development technology and experienced staff". In this sense the staff training is important for the success of the IT adoption (Wang et al., 2010:175). Thus the organisational readiness can be regarded as a significant internal driver for the e-business adoption (Bayo-Moriones \& Lera-López, 2007; Salwani et al., 2009).

The manager/proprietor IT knowledge and skills is the fourth factor, which impact positively and significantly the e-business adoption ( $\mathrm{H} 5 \mathrm{~b})$. Previous studies also found that top managers with higher IT experience are more likely to support the new technology implementation (Caldeira \& Ward, 2002; Ghobakhloo et al., 2011). According to Eikebrokk and Olsen (2007:367) the most fundamental challenge to SMEs may lie in changing the mind-set of the organization, which depends to a great degree on the managers' personal IT experience (Palvia \& Palvia, 1999).

In this study the firm size influences positively and significantly the e-business acceptance, although less strongly than the above mentioned factors (H5a). Some larger firms have a disadvantage known as "structural inertia" (deeply rooted organisational routines), which may impact negatively the IT adoption (Peixin \& Xie, 2012:28). The descriptive analysis showed that most of the sample companies are small and relatively young, which makes it unlikely to suffer of the "structural inertia". On the contrary, smaller firms are more likely to have weaker resources (Johnson, 2010) and insufficient IT knowledge (Riemenschneider et al., 2003), which can hamper their IT development. Brown and Kaewkitipong (2009:223) found that in comparative terms the technology adoption gap between large and the smaller SME travel agents is very significant. Vlachos (2013:194) revealed that small companies prevailed among beginners and late adopters of ebusiness technologies and these companies are most disadvantages in respect to the new technologies. 
The expected disadvantages and obstacles are the factor, which includes fear of none return of high IT investments, lack of trust in the online transactions, unstable niche of online customers, insufficient staff IT preparedness, and loss of personal relations, and which impacts negatively the e-business adoption $(\mathrm{H} 2 \mathrm{~b})$. The negative role of these attitudes on the e-business adoption was confirmed by other researches too (Lu et al., 2002; Stockdale \& Standing, 2006; Oliveira \& Martins, 2010). Vrana and Zafiropoulos (2006:603) reported that many tourism agencies in Greece did not use extensively the IT, because of a small share of online transactions and a weak social pressure for the IT adoption.

The perceptions of the shadow economic practices in the sector form the next factor, which role on the e-business adoption has not been studied yet. This factor impacts significantly and negatively the new technology acceptance by small tourism firms $(\mathrm{H} 2 \mathrm{a})$. Its influence is even stronger compared to the influence of managers' negative attitudes. Oxley and Yeung (2001) also found that the institutional milieu in terms of level of taxes, regulations, informal deals, etc. play an important role by stimulating or hampering the new technology acceptance. According to Kshetri (2007:446) the development of ecommerce is negatively affected by problems in economic and social areas, an important part of which is the shadow economy.

The obtained results show positive correlations among positive managers' attitudes, environmental context, organisational readiness, manager's IT experience, and firm size $(\mathrm{H} 3 \mathrm{~b})$ (Table 6). These factors are negatively correlated with the perceptions of shadow economic practices in the sector $(\mathrm{H} 3 \mathrm{a})$. On the contrary, the managers' negative attitudes are positively correlated with the shadow economy perceptions ( $\mathrm{H} 4 \mathrm{a})$, and negatively with other factors (organizational readiness, industry environment, manager experience, and firm size) ( $\mathrm{H} 4 \mathrm{~b})$. This suggests that the week institutions, which permit the existence of a significant amount of shadow economy, would diminish the effects of the first group of factors, which enhance the e-business adoption (Anderson et al., 2004). At the same time the positive correlation between negative managers' attitude and perceptions of shadow economy implies that they may strengthen mutually each other, but this hypothesis needs further research.

Shadow economy as a barrier to the ebusiness adoption

The European Parliament report noted that "the size of the shadow economy in the EU in 2012 is estimated at slightly more than EUR 2.35 trillion, which is about $18.4 \%$ of EU's Gross Domestic Product (GDP)" (European parliament, 2013:10). The Visa Europe study (2011:7) stressed that the payment in cash is regarded to be one of the most important enablers of the shadow economy, because it is easy to use and difficult to trace.

The fact that small firms can perform well without new technology adoption, and instead being inspired by the shadow economic practices, is not new. The weak institutions, particularly in the emergent and transition economies, stimulates some entrepreneurs to operate informally in order to survive and even sometimes to succeed (Smallbone \& Welter, 2001; Xheneti \& Smallbone, 2008). A not negligible number of interviewed managers shared that the State did not protect correct tourist agents from those, applying shadow economic practices. The latter can avoid paying taxes, which allows them to offer lower prices (R2, R5, R6, R9, R20, and R23). The chair of the Bulgarian Tourism Chamber considered that the "grey economy" in the tourism was no less than $40 \%$, according to the brand association (http://www.biabg.com/news/3). The non-satisfactory degree of the e-business adoption by the Bulgarian small tourism firms might be due also to these circumstances. The country scored high on the size of shadow economy among 39 OECD countries (34.6\%) (Schneider \& Buehn, 2013:14), and it had not a good position on the official regulations and corruption indexes (World Bank, 2013).

According to the one of the interviewed small tourism firm's manager (R8), most challenging for the e-business adoption is not the cost, but the staff preparedness. He considered that there was a small number of people acquainted 
with online reservation and payment systems. This situation required staff training, which was not always efficient because of the staff overloading and lack of time. Employees had to learn during the work, which hampered the quality of services. Among other issues he underlined the relationships with partners and particularly with banks, as the market gets ahead the regulations.

The interviewed managers highlighted that the clients had not still confidence in the online transaction, particularly after some signals in press about personal and credit cards' data abuses (R3, R5, R6, R10, R17, R22, and R28). Even some of the high-stars hotels preferred customers to pay on spot instead online, mainly because of high commissions hotels have to pay to banks and intermediaries (R1). "We provide an online reservation, but not an online payment. This is because the value of our tourist packages is high, and the commissions to banks and other financial institutions become great" (R11).

The manager of the online mediator Hotels.bg outlined the typical way the Bulgarian tour operators are working as following:

"The client chooses a hotel or a particular offer, sends email or calls the operator by telephone. After receiving a call, the operator sends an inquiry to a hotel, and if there are available places (for biggest hotels this information is always available), confirms back to the client. The client pays with bank transfer or in the firm's office and receives voucher, with which accommodates in a hotel. Sometimes this type of reservation takes several days until the hotel confirms the request".

Managers were concerned with the opportunity for stealing a freely provided information on innovative products and services, and related partners (R8). Some of them stated that this way they facilitated the competitors in their marketing researches (R23). Other difficulties exist with smaller hotels, guest houses, etc., as they are often unwilling to make concession to tour operators (R11, R15, R16, and R18). Additional issues came from the discrepancy between what hotels present online (photos, free services, rooms, cleanness, etc.), and what clients see on place (R7, R25, and R30).

Uzoka et al. (2007) found that many SME websites (especially in developing countries) have been designed to promote only the company products and services. If the frontend functionalities of the firms' websites are important success factors (Wen et al., 2003), namely the online payment is problematic in emergent and transition economies. Lu et al. (2002:204, 205) observed that "it is very weak in online booking, ordering and payment in China... some tourism websites did not have online booking facilities... Users have to make a phone call or fax for booking". According to Molla and Licker (2005) the payment with credit card through the firms' websites was a main security concern among small and medium enterprises.

Saidoune (2013) shared similar considerations from Algeria, where paying online for different goods and services (ticket, fuel, telephone bills, etc.) is not possible, as the reluctance is coming from all parties, including banks and merchants. "The real resistance is actually coming from the informal sector which presents the main obstacle to electronic banking and the development of electronic commerce..." This is because "the use of POS allows some sort of banking traceability that generally subjects traders to a flat tax preceding a tax adjustment; and such a thing won't be accepted easily" (Saidoune, 2013). Yaqub et al. (2013:200) also pointed out that in Nigeria, like in many developing countries, cash is the main mode of payment. Besides some conveniences of cash payment, it allows for more anonymity, revenue leakage, higher informal sector, etc. Particularly it makes taxation less transparent, while the epayment systems bring hidden transactions into the banking system, and thus helps reducing shadow economy. Tandon (2002:3) considered that the application of IT might push the businesses from informal to formal economies "and while this may be desirable from a national economy perspective, it might not be considered desirable from an individual entrepreneurs' perspective".

Other authors have reported a surprising increase of the e-commerce through the 
Table 8. Correlations among 36 European countries' scores on three competitiveness indexes and the size of country's shadow economy (Pearson coefficient)

\begin{tabular}{lllll} 
& $\begin{array}{l}\text { NRI Score } \\
(2009-2010)\end{array}$ & $\begin{array}{l}\text { GCI Score } \\
(2009-2010)\end{array}$ & $\begin{array}{l}\text { TTCI Score- } \\
(2009)\end{array}$ & $\begin{array}{l}\text { Size of shadow economy } \\
(1996-2006)\end{array}$ \\
\hline NRI Score 2009-2010 & 1 & $0.969^{* *}$ & $0.875^{* *}$ & $-0.790^{* *}$ \\
GCI Score 2009-2010 & $0.969^{* *}$ & 1 & $0.871^{* *}$ & $-0.799^{* *}$ \\
TTCI Score 2009 & $0.875^{* *}$ & $0.871^{* *}$ & 1 & $-0.832^{* *}$ \\
Size shadow economy 1996-2006 & $-0.790^{* *}$ & $-0.799^{* *}$ & $-0.832^{* *}$ & 1 \\
\hline
\end{tabular}

${ }^{1}$ The Networked Readiness Index 2009-2010 (The Global Information Technology Report 2009-2010);

${ }^{2}$ The Global Competitiveness Index 2009-2010 (World Economic Forum 2009);

${ }^{3}$ Travel and Tourist Competitiveness Index 2009 (The Travel \& Tourism Competitiveness Report 2009);

${ }^{4}$ Size of the Shadow Economy (available at:

http://www.econ.jku.at/members/Schneider/files/publications/ShadEconomy Corruption_rev_091009.pdf).

massive use of mobile phones by small businesses in a developing country like Kenya (Omwansa, 2009; Mbogo, 2010). The study of Litondo and Ntale (2013:19) found that $95 \%$ of micro- and small enterprises "possessed mobile phones and $84 \%$ use them to transact business". The reason of this widespread mobile e-commerce is that it is affordable, easy to use, and portable. This type of doing ebusiness, however, does not disturb its informal character. The mobile e-commerce simply facilitates the cash delivery between microbusinesses and their suppliers and clients (Mbogo, 2010:182). Not surprisingly it is not clear how these services should be regulated (Omwansa, 2009:122). Placing regulations on these practices would be difficult and not well accepted by small firms of the informal sector.

The results from a Table 8 reveal that the size of the countries' shadow economy is significantly and negatively correlated with some major competition indexes - Networked Readiness Index (NRI); Travel and Tourist Competitiveness Index (TTCl), and Global Competitiveness Index (GCl).

These data support the findings that there is a strong correlation between the size of a country's shadow economy and the level of use of e-payments within the country. For instance, in both the UK and the Netherlands, a large share of payments is made by electronic payment methods. Both of these countries also have smaller shadow economies than those countries which have a low level of electronic payments (Visa Europe, 2011:7).
Based on that we may conclude that the nonwillingness of some small tourism managers to adopt the e-business might be due, among other reasons, to their desire to keep the business non transparent.

\section{Conclusion}

The goal of this study was to reveal the factors, which influence the e-business adoption by the Bulgarian small tourism firms with an accent on the role played by the shadow economic practices in the sector on this process. The exploratory factor analysis provided five factors as antecedents to the e-business adoption. These factors reflected perceptions of environmental pressure, organisational readiness, shadow economy in the sector, and managers' attitudes (positive and negative) towards the e-business adoption. The positive attitudes were related to the expected benefits, while the negative ones were tied to the expected disadvantages and barriers. The ebusiness adoption was assessed by four aspects - website functionalities in terms of online reservation and payment systems, and back end integration systems. The effects of these factors were revealed by a multiple regression model, which included also manager experience and firm size as control variables. The findings suggested that environmental pressure, organisational readiness, and positive expectations were more likely to drive the e-business adoption. The manager experience and the firm size influenced positively this adoption too. On the contrary, negative expectations and particularly the perceptions of the spread up of shadow 
economy were more likely to work against the e-business adoption by small tourism firms.

The policy implications from these results are that strengthening institutions and decreasing the attractiveness of the shadow economy could have positive impact on the e-business adoption by small tourism firms. It was demonstrated that more severe regulations (public sector taxation and product market regulations) tend to restrict shadow economy (Georgiou, 2013:5). The improvements in the quality of institutions might work much better in reducing the size of the underground economy than other measures of deterrence (Feld \& Schneider, 2010). Other studies have shown that the online shopping create transparency and hinders the shadow economy as it limits the opportunity to under-report. The use of electronic payment systems makes operating in the shadow economy more difficult due to the trace left by each transaction (European Parliament, 2013:39). The Visa Europe report (2013:14) suggested that increasing electronic payment by $10 \%$ annually for at least four consecutive years can shrink the shadow economy by 5 percent.

The implications for managers of small tourism firms are that the benefits of the e-business adoption may exceed significantly the perceived disadvantages and obstacles, as the online tourism markets became more important in comparison to offline ones. Many researches have proven that the e-business leads to greater opportunities for reaching new clients, expanding market share, improving communication, and reducing costs. In this light the advantages received by resorting to shadow practices are temporary, compared to the sustainable advantages of the innovation technology adoption (Clayton \& Criscuolo, 2002; Blake et al., 2006). At the same time, the IT implementation assumes re-engineering in the entire processes of managing and marketing touristic products and destinations (Buhalis \& Law, 2008). The e-business adoption is difficult as it disrupts traditional ways of doing business (Kendall \& Kendall, 2001). It requires significant organisational change, which is particularly difficult for small firms (McAdam \& McConvery, 2004). Because of that the small firms need higher government support in terms of special educational and innovation promotional programmes, and less expensive IT infrastructure.

According to Weill and Vitale (2002:18) the firms will evolve their business models, combining the best of the physical and electronic worlds. The "bricks and clicks" model represents namely businesses that have both an offline, "real world" store and an online presence in the form of an e-commerce store. Additionally, the technological development (web 2, etc.) allows for smaller tourism firm to recover their retardation and to implement the newest functionalities in their website. As Sigala (2007:1) observed "many new types of tourism cyber-intermediaries have been created that are nowadays challenging the ebusiness model of existing cyber-intermediaries that only few years ago have been threatening the existence of intermediaries!" The web 2.0 enable internet users to become the coproducers, the co-designers, the co-marketers and the co-distributors of tourism experiences and services as well as the co-entrepreneurs of new e-business models (Sigala, 2007:6).

One of the limitations of this research refers to the subjective opinions of the interviewed managers. Their responses might be bias towards higher values as the process of digitalization in tourism seems irreversible. Other limitation is related to the sample size, as one needs greater sample in order to measure the factors' influence on different tourism agents separately. Other constraint comes from the number of factors relevant to the ebusiness adoption, as it is always restricted by necessity of modelling. It was found that the significance of different factors on the IT acceptance depends also on the stage of their implementation (Dholakia \& Kshetri, 2004:319), specific business cultures (Gibbs et al., 2003), and level of the IT country development (Lu et al., 2002:192). These variables, however, were not included in the present paper. Further researches are needed to investigate the complex interactions of firm, sector, country, and culture levels factors, which influence the new technology adoption by small tourism firms. 
Acknowledgment: The author would like to thank Prof. Allan Williams, two anonymous referees, and editors for their valuable comments and suggestions. The empirical part of the paper was accomplished in the frame of the project "E-tourism as a factor for the Bulgarian tourism firms' competitiveness in the post-crisis period", while the article was submitted under the Marie Curie Fellowship at the University of Surrey, 2014 (GA No 327405).

\section{References}

Abou-Shouk, M., Lim, W.M., \& Megicks, P. (2013). E-Commerce and Small Tourism Businesses in Developing Countries: Drivers versus Boundaries of Adoption. Tourism Planning \& Development, 10(3), 249-266.

Abou-Shouk, M., Megicks, P. \& Lim, W.M. (2012). Perceived Benefits and ECommerce Adoption by SME Travel Agents in Developing Countries: Evidence from Egypt, Journal of Hospitality \& Tourism Research, 37(4), 490-515.

Al-Qirim, N. (2007). The adoption of ecommerce communications and applications technologies in small businesses in New Zealand. Electronic Commerce Research and Applications, 6(4), 462-473.

Amit, R. \& Zott, C. (2001). Value creation in ebusiness. Strategic Management Journal, 22, 493-520.

Anderson, T., Serger, S.S., Sörvik, J., \& Hansson, E.W. (2004). The Cluster Policies Whitebook, IKED, URL: http:// lup.lub.lu.se/luur/download?func $=$ downloa dFile\&recordOId=1304063\&fileOId=13040 64. (Accessed on March 12, 2014)

Baldwin, J. R., Sabourin, D., \& Smith, D. (2004). Firm performance in the Canadian food processing sector: the interaction between ICT, advanced technology use and human resource competencies. In: OECD (Ed.). The Economic Impact of ICT. Measurement, Evidence and Implications. 153-181. Paris: OECD

Bao, J., \& Sun, X. (2010). A Conceptual Model of Factors Affecting e-Commerce Adoption by SMEs in China, Computer society. URL: http://ieeexplore.ieee.org/ $\mathrm{xpl} /$ articleDetails.jsp?reload=true\&arnumb er $=5628654$. (Accessed on December 1, 2013)

Bayo-Moriones, A. \& Lera-López. F. (2007). A firm-level analysis of determinants of ICT adoption in Spain, Technovation, 27, 352366.

Beckinsale, M., Ram, M., \& Theodorakopoulos, N. (2010). ICT adoption and ebusiness development: Understanding ICT adoption amongst ethnic minority businesses. International Small Business Journal, 29(3), 193-219.

Beekhuyzen, J., Hellens, L. \& Siedle, M. (2005). Cultural barriers in the adoption of emerging technologies.URL:http://140. 131.24.185/prof-rtlin/Research_theory_ Data/F.2005HCl\%E6\%96\% 87\%E5\%8C \% 96\%E8\%AB\%96\%E6\%96\%87/1813.pdf. (Accessed on December 16, 2013)

Bennett, M.M. \& Lai, C.K. (2005). The impact of the internet on travel agencies in Taiwan. Tourism and Hospitality Research, 6(1), 823.

Blake, A., Sinclair, M.T. \& Campos Soria, J. A. (2006). Tourism Productivity Evidence from the United Kingdom. Annals of Tourism Research, 33(4), 1099-1120.

BIA (2009) $40 \%$ is the "shadow" economy in the tourism, considered from the branch association, 07.09.2009, URL: http://www. bia-bg.com/news/3. (Accessed on May 10, 2013)

Boateng, R., Molla, A. Heeks, R. \& Hinson, R. (2008). E-commerce and Socio-economic Development: Conceptualising the Link. Internet Research, 18(5), 562-592.

Bordonaba-Juste, V., Lucia-Palacios, L. \& Polo-Redondo, Y. (2012). Antecedents and consequences of e-business adoption for European retailers. Internet Research, 22(5), 532-550.

Brown, D.H. \& Kaewkitipong, L. (2009). Relative size and complexity: e-business use in small and medium sized tourism enterprises in Thailand. Journal of Enterprise Information Management, 22 (1/2), 212-231

Buhalis, D. (2003). eTourism: Information Technology for Strategic Tourism Management. London, UK: Pearson (Financial Times/Prentice Hall).

Buhalis, D. \& Law, R. (2008). Progress in information technology and tourism 
management: 20 years on and 10 years after the internet - The state of the eTourism research. Tourism Management, 29(4), 609-623.

Buhalis, D. \& Licata, M. C. (2002). The future of eTourism intermediaries, Tourism Management, 23, 207-220.

Buhalis, D. \& Jun, S.H. (2011). E-Tourism. International Centre for Tourism and Hospitality Research, Bournemouth University, UK. Woodeaton, Oxford: Goodfellow Publishers Limited. URL: http://www.goodfellowpublishers.com/free files/fileEtourism.pdf. (Accessed on October 1, 2014)

Caldeira, M.M. \& Ward, J.M. (2002). Understanding the successful adoption and use of IS/IT in SMEs: An explanation from Portuguese manufacturing industries. Information Systems Journal, 12, 121-152.

Chang, S.-I., Hung, S.-Y., Yen, D.C. \& Lee:-J. (2010). Critical Factors of ERP Adoption for Small- and Medium- Sized Enterprises: An Empirical Study. Journal of Global Information Management, 18(3), 82-106.

Chen, L. \& Holsapple, C.W. (2013). E-business adoption research: state of the art. Journal of Electronic Commerce Research, 14(3), 261- 286.

Chibelushi, C. \& Costello, P. (2009). Challenges facing $W$. Midlands ICToriented SMEs. Journal of Small Business and Enterprise Development, 16(2), 210239.

Chong, A.Y-L., Ooi, K-B., Lin, B. \& Tang, S.Y. (2009). Influence of interorganizational relationships on SMEs' e-business adoption. Internet Research, 19(3), 313331.

Chong, S. (2008). Success in electronic commerce implementation: A crosscountry study of small and medium-sized enterprises. Journal of Enterprise Information Management, 21, 468-492.

Clayton, T. \& Criscuolo, Ch. (2002). Electronic Commerce and Business Change. Economic Trends, 583, 62-69.

Cooper, J. \& Burgess, L. (2000). A Model of Internet Commerce Adoption (MICA). In S. Rahman, \& M. Raisinghani (Eds.). Electronic commerce: opportunity and challenges, 189-201. London: Idea Group Publishing.
Cosgun, V. \& Dogerlioglu, O. (2012). Critical Success Factors Affecting e-commerce Activities of Small and Medium Enterprises. Information Technology Journal, 11(12), 1664-1676.

Damanpour, F. (1991). Organizational Innovation: A Meta-Analysis of Effects of Determinants and Moderators. The Academy of Management Journal, 34(3), $555-590$

Daniel, E., Wilson, H. \& Myers, A. (2002). Adoption of e-commerce by SMEs in the UK: towards a stage model. International Small Business Journal, 20, 253-270.

Davis, F.D. (1993). User acceptance of information technology: system characteristics, user perceptions and behavioral impacts. International Journal of Management-Machine Studies, 38, 475-487

Davis, F.D., Bagozzi, R.P. \& Warshaw, R. (1989). User acceptance of computer technology: A comparison of two theoretical models. Management of Science, 35(8), 982-1003

Demetriades, S. \& Baltas, G. (2003). Electronic Commerce and Marketing. Athens: Rosili Publications.

Dholakia, R. R. \& Kshetri, N. (2004). Factors impacting the adoption of the internet among SMEs, Small Business Economics, 23(4), 311 - 322.

Dinlersoz, E. M. \& Pereira, P. (2007). On the diffusion of electronic commerce. International Journal of Industrial Organization, 25(3), 541 - 574.

Doolin, B., Burgess, L. \& Cooper, J. (2002). Evaluating the use of the web for tourism marketing: a case study from New Zealand. Tourism Management, 23 (5), 557-561.

Eikebrokk, T.R. \& Olsen, D.H. (2007). An empirical investigation of competency factors affecting e-business success in European SMEs. Information \& Management, 44, 364-383.

Euromonitor Report (2011). Bulgaria Retail Travel, 2011. URL: http://www. slideshare.net/reportsnreports/travel-andtourism-in-bulgaria. (Accessed on January 10, 2013)

European Parliament. Directorate General for Internal Policies. Policy department A. 
Economic and Scientific Policy. (2013). From Shadow to Formal Economy: Levelling the Playing Field in the Single Market. European Union, 2013. URL: http://www.europarl.europa.eu/meetdocs/ 2009_2014/documents/imco/dv/studylevell ingplayingfield_/studylevellingplayingfield en.pdf (Accessed on May 20, 2014)

European Travel Commission (ETC) Online Travel Market. (2013a). URL: http://www. newmediatrendwatch.com/world-overview/ 91-online-travel-

market?start=1. (Accessed on August 9, 2013)

European Travel Commission (ETC) Regional Overview (Europe). (2013b). URL:http://www.newmediatrendwatch.com /regional-overview/103-europe?start=2. (Accessed on August 19, 2013)

Fabiani, S., Schivardi, F. \& Trento, S (2005). ICT adoption in Italian manufacturing: firm-level evidence. Industrial and Corporate Change, 14(2), 225-249.

Falk, M. (2005). ICT-linked firm reorganisation and productivity gains. Technovation, 25(11), 1229-1250.

Feld, L.P. \& Schneider, F. (2010). Survey on the shadow economy and undeclared earnings in OECD countries. German Economic Review, 11, 109-149.

Fillis, I. \& Wagner, B. (2005). E-business Development. An Exploratory Investigation of the Small Firm. International Small Business Journal, 23(6), 604-634

Fishbein, M. \& Ajzen, I. (1975). Belief, attitude, intention and behavior: An introduction to theory and research. Massachusetts, CA: Addison-Wesley, Reading,

Foley, P. \& Ram, M. (2002). The use of online technology by ethnic minority businesses: a comparative study of the West Midlands and UK. De Montfort University, Leicester. URL: www.sbs.gov.uk/content/ research/ EMB IT.pd (Accessed on October 1, 2014)

Galloway, L. (2006). Information and communications technologies and e-business. In Deakins, D., \& Freel, M. (Eds.) Entrepreneurship and Small Firms, 4th edition. Berkshire: McGraw-Hill, 139-156.

Georgiou, M. N. (2013). Regulations and Shadow Economy. A Worldwide Panel
Data Analysis. URL: http://papers. ssrn.com/sol3/papers.cfm?abstract id=23 63382 (Accessed on May 1, 2014)

Ghobakhloo, M., Sabouri, M.S., Hong, T.S., \& Zulkifli, N. (2011). Information Technology Adoption in Small and Medium-sized Enterprises; An Appraisal of Two Decades Literature. Interdisciplinary Journal of Research in Business, 1(7), 53-80.

Gibbs S., Sequeira J. \& White M. M. (2007). Social Networks and Technology Adoption in Small Business. International Journal of Globalisation and Small Business, 2(1), 66-87.

Gibbs, J., Kraemer, K. L. \& Dedrick, J. (2003). Environment and Policy Factors Shaping Global E-Commerce Diffusion: A CrossCountry Comparison. Information Society, 19 (1), 5-18.

Gong, W. (2009). National culture and global diffusion of business-to consumer ecommerce. Cross Cultural Management: An International Journal, 16(1), 83-101.

Grandon, E. \& Pearson, J. M. (2004). Electronic commerce adoption: An empirical study of small medium US businesses. Information \& Management, 42(1), 197-216.

Gunasekaran, A. \& Ngai, E.W.T. (2005). Ecommerce in Hong Kong: an empirical perspective and analysis. Internet Research, 15(2), 141-159.

Hair, J. F. Jr., William, C.B., Barry, J. B., \& Anderson, R. E. (2010). Multivariate data analysis. A Global Perspective (7th Ed.). Upper Saddle River, NJ: Pearson Prentice Hall.

Hong, W., \& Zhu, K. (2006). Migrating to internet-based e-commerce: factors affecting e-commerce adoption and migration at the firm level. Information \& Management, 43(2), 204-221.

Hsu:F., Kraemer, K.L. \& Dunkle, D. (2006). Determinants of e-business use in US firms. International Journal of Electronic Commerce, 10(4), 9-45.

Humphrey, J., Mansell, R., Paré, D. \& Schmitz, H. (2003). The Reality of E-commerce with Developing Countries. URL: http://eprints.Ise.ac.uk/3710/1/The_reality of_e-commerce_with_developing_countries.pdf. (Accessed on November 20, 2013) 
lacovou, C. L., Benbasat, I. \& Dexter, A. S. (1995). Electronic data interchange and small organizations: Adoption and impact of technology, MIS Quarterly, 19(4), 465 485.

Ifinedo, P. (2011). Internet/e-business technologies acceptance in Canada's SMEs: an exploratory investigation. Internet Research, 21(3), 255-281.

Jabeur, F., Mohiuddin, M. \& Karuranga, E. (2013). Timeline of Initial Perceptions and Adoption of e-Business among Quebec Forestry Sector SMEs. Communications of the IIMA, 13(3), 1-20.

Jeon, B.N., Han, K.S. \& Lee, M.J. (2006). Determining factors for the adoption of Ebusiness: The case of SMEs in Korea. Applied Economics, 38, 1905-1916.

Johnson, M. (2010). Barriers to innovation adoption: a study of e-markets, Industrial Management \& Data Systems, 110, 157174.

Jones, P., Packham, G., Beynon-Davies, P. \& Pickernell, D. (2011). False promises: Ebusiness deployment in Wales' SME community. Journal of Systems and Information Technology 13(2), 163-178.

Kabir, M.A., Jahan, K., Adnan, Md. N. \& Khan, N. (2012). Business Model of E-Tourism for Developing Countries. International Journal of Computer and Information Technology: 30-34. URL: http://www.ijcit. org/ijcit papers/vol3no1/IJCIT-120705.pdf (Accessed on October 12, 2014)

Karakaya, F. \& Shea, T. (2008). Underlying Motivations for Establishing E-commerce Business and their Relationship to $E$ commerce success. Journal of Internet Commerce, 7(2), 153-179.

Kaynak, E., Tatoglu, E. \& Kula, V. (2005). An analysis of the factors affecting the adoption of electronic commerce by SMEs: Evidence from an emerging market. International Marketing Review, 22, 623-640.

Kendall J.E., \& Kendall K.E. (2001). A paradoxically peaceful coexistence between commerce and e-commerce. Journal of Information Technology Theory and Application, 3(4), 1-6.

Kshetri, N. (2007). Barriers to e-commerce and competitive business models in developing countries: A case study.
Electronic Commerce Research and Applications, 6(4), 443-452.

Kshetri, N. (2010). Normative and cognitive institutions affecting a firm's e-commerce adoption. Journal of Electronic Commerce Research, 11(2), 157-174.

Kwun, O., Nickels, D., Alijani, G.S. \& Omar, A. (2010). The perceived strategic value of ecommerce in the face of natural disaster: E-commerce adoption by small businesses in post-Katrina New Orleans. International Journal of Entrepreneurship, $14,71-84$

Law, R. (2001). Internet and Tourism-Part VI: Priceline.com - Exploring the "Name Your Own Price" Model. Journal of Travel \& Tourism Marketing, 11(4), 97-102.

Lawson, R., Alcock, C., Cooper, J. \& Burgess, L. (2003). Factors affecting adoption of electronic commerce technologies by SMEs: an Australian study. Journal of Small Business and Enterprise Development, 10(3), 265-276.

Lee, Y, Kozar, K.A. \& Larsen, K.R.T. (2003). The technology acceptance model: past, present, and future. Communication of the AIS, 12(50), 752-780.

Lee, S., \& Kim, K. J. (2007). Factors affecting the implementation success of internetbased information systems. Computers in Human Behaviour, 23(4), 1853-1880.

Lefebvre, L., Lefebvre, E., Elia, E. \& Boeck. H (2005). Exploring B-to-B ecommerce adoption trajectories in manufacturing SMEs. Technovation, 25(12), 1443 - 1456.

Legris, P., Ingham, J., \& Collerette, P. (2003). Why do people use information technology? A critical review of the technology acceptance model. Information \& Management, 40, 191-204.

Levy, M. \& Powell: (2002). SME Internet Adoption: Towards a Transporter Model, 15th Bled Electronic Commerce Conference eReality: Constructing the eEconomy, Bled, Slovenia, June 17 - 19, 2002. URL:http://www.bledconference.org/ proceedings.nsf/0/17612f82c49eed3bc12 56e9f00362125/\$FILE/levy.pdf (Accessed on October 10, 2013)

Lewis, R. \& Cockrill, A. (2002). Going global remaining local: the impact of e-commerce on small retail firms in Wales. International 
Journal of Information Management, 22, 195-209.

Liew, V. (2009). E-Commerce Usage by the SMEs in Northern Malaysia: Analysis of the State of E-Commerce Adoption by the SMEs in Northern Malaysia and Factors that Might Hinder its Adoption: An Empirical Study, VDM Verlag.

Lin, H.F. \& Lin, S.M. (2008). Determinants of ebusiness diffusion: a test of the technology diffusion perspective, Technovation, 28, 135-145.

Litondo, K.O., \& Ntale, J.F. (2013). Determinants of Mobile Phone Usage for E-Commerce among Micro and Small Enterprises in the Informal Sector of Kenya. International Journal of Applied Science and Technology, 3(6), 16-23

Love: E. D., Irani, Z., Standing, C., Lin, C. \& Burn, J. M. (2005). The enigma of evaluation: benefits, cost and risks of IT in Australian small medium-sized enterprises. Information and Management, 42(7), 947 - 964.

Lu, Z., Lu, J. \& Zhang, Ch. (2002). Website Development and Evaluation in the Chinese Tourism Industry, Networks and Communication Studies, NETCOM, 16(34), 191-208.

Lucchetti, R. \& Sterlacchini, A. (2004). The adoption of ICT among SMEs: Evidence from an Italian survey. Small Business Economics, 23(2), 151-168.

Ludivine, M. (2009). Understanding the implementation of e-business strategies: Evidence from Luxembourg, MPRA Paper, 13645, University Library of Munich, Germany.

Lun, Y.H.V. \& Quaddus, M.A. (2011). Firm size and performance: A study on the use of electronic commerce by container transport operators in Hong Kong. Expert Systems with Applications, 38, 7227-7234.

MacGregor, R. \& Vrazalic, L. (2004). Electronic Commerce Adoption in Small to Medium Enterprises (SMEs). A Comparative Study of SMEs in Wollongong (Australia) and Karlstad (Sweden). URL: https://www.uow.edu.au/content/groups/p ublic/@web/@commerce/@econ/docume nts/doc/uow 012275.pdf. (Accessed on December 20, 2013)
Manucci, J. (2010). Different Types of eBusiness Models Ebusiness. URL: http://www.insidebusiness360.com/index.p $\mathrm{hp} /$ different-types-of-e-business-modelsebusiness-8702/ (Accessed on September 09,2014 )

Mbogo, M. (2010). The Impact of Mobile Payments on the Success and Growth of Micro-Business: The Case of M-Pesa in Kenya. The Journal of Language, Technology \& Entrepreneurship in Africa, 2(1), 182-203.

McAdam, R., \& McConvery, T. (2004). Barriers to innovation within small firms in a peripheral location. International Journal of Entrepreneurial Behaviour \& Research, 10(3), 206-221.

McKechnie, S., Winklhofer, H. \& Ennew, C. (2006). Applying the technology acceptance model to the online retailing of financial services. International Journal of Retail \& Distribution Management, 34 (4/5), 388-410.

Mehrtens, J., Cragg:B. \& Mills, M. (2001). A model of internet adoption by SMEs. Information and Management, 39(3), 165176.

Migiro, S. O. \& Ocholla, D.N. (2005). Information and Communication Technologies in Small and Medium Scale Tourism Enterprises in Durban, South Africa. Information Development, 21(4), 283-294.

Mohamad, R. \& Ismail, N.A. (2009). Electronic commerce adoption in SME: the trend of prior studies. Journal of Internet Banking and Commerce, 14(2), 1-16.

Molla, A. \& Licker, S. (2005). E-Commerce adoption in developing countries: a model and instrument. Information \& Management, 42, 877-899.

Morrison, A.J. \& King, B.E.M. (2002). Small tourism businesses and e commerce: Victorian tourism online. Tourism and Hospitality Research, 4(2), 104-115.

National Statistical Institute (NSI). (2014). Electronic commerce. URL: http://www.nsi.bg, (Accessed on June 1, 2014)

Niininen, O., Buhalis, D. \& March, R. (2007). Customer Empowerment in Tourism through Consumer Centric Marketing (CCM). Qualitative Market Research: An International Journal, 10(3), 265-281. 
Factors for the e-business adoption by small tourism firms and the role of shadow economic practices.

Nikabadi, M.S. \& Jafarian, A. (2012). Framework for Selecting an Appropriate E-Business Model in SMEs. International Journal of E-Business Development, 2(3), 86-96.

O'Donnell A., Gilmore A, Cummins, D. \& Carson, D. (2001). The Network Construct in Entrepreneurship Research. A Review and Critique Management Decision, 39(9), 749-760.

OECD (2004). ICT, e-business and SMEs. OECD, Paris.

OECD (2012). Forum on Tax Administration: SME Compliance Sub-Group. Information note - Reducing opportunities for tax noncompliance in the underground economy. URL: $\quad$ http://www.oecd.org/site/ctpfta/ 49427993.pdf (Accessed on January 12, 2014)

Oliveira, T. \& Martins, M. F. (2010). Firms' patterns of e-business adoption: evidence for the European Union-27, The Electronic Journal Information Systems Evaluation, 13, 47-56.

Oliveira, T. \& Martins, M.F. (2011). Literature Review of Information Technology Adoption Models at Firm Level. The Electronic Journal Information Systems Evaluation, 14(1), 110-121.

Omwansa, T. (2009). M-PESA: Progress and Prospects. Innovations Case Discussion: M-PESA. Innovations/Mobile World Congress. URL: http://www.strathmore.edu/ pdf/innovgsma-omwansa.pdf. (Accessed on December 21, 2013)

Oreku, G.S., Li, J., Kimeli, K. \& Mtenzi, F. (2009). State of Tanzania e-readiness and e-commerce: overview. Information Technology for Development, 15(4), 302311.

Oxley, J. E. \& Yeung, B. (2001). E-Commerce Readiness: Institutional Environment and International Competitiveness. Journal of International Business Studies, 32(4), 705-723.

Palvia, P. \& Palvia, S. (1999). An examination of the IT satisfaction of small business users. Information and Management, 35, 127-137.

Pan, M. J., \& Jang, W. Y. (2008). Determinants of the adoption of enterprise resource planning within the technology- organization-environment framework: Taiwan's communications, Journal of Computer Information Systems, 48, 94102.

Parker, C.M. \& Castleman, T. (2009). Small firm e-business adoption: a critical analysis of theory. Journal of Enterprise Information Management, 22(1/2), 167182.

Pavic, S., Koh, S.C.L., Simpson, M. \& Padmore, J. (2007). Could e-business create a competitive advantage in UK SMEs? Benchmarking: An International Journal, 14, 320-351.

Pavlou, A. \& El Sawy, O.A. (2010). The "Third Hand": IT-enabled competitive advantage in turbulence through improvisational capabilities. Information System Research, 21(3), 443-471.

Pease, W. \& Rowe, M. (2005). An overview of information technology in the tourism industry. URL: http://eprints.usq.edu.au 1245/1/Pease.pdf, (Accessed on: November 21, 2013)

Peixin, L. \& Xie, W. (2012). A strategic framework for determining e-commerce adoption. Journal of Technology Management in China, 7(1), 22-35.

Peng, Y.-C., Trappey, C. V. \& Liu, N.-Y. (2005). Internet and e-commerce adoption by the Taiwan semiconductor industry, Industrial Management \& Data Systems, 105(4), 476-490.

Pham, L., Pham, L.N. \& Nguyen, D.T.T. (2011). Determinants of e-commerce adoption in Vietnamese small and medium sized enterprises. International Journal of Entrepreneurship, 15, 45-72.

Pikkarainen, T., Pikkarainen, K., Karjaluoto, H. \& Pahnila, S. (2004). Consumer acceptance of online banking: an extension of the technology acceptance model. Internet Research, 14, 224-235.

Poon, S. \& Swatman, P. (1999). An exploratory study of small business internet commerce issues. Information and Management, 35, 9-18.

Ramdani, B., \& Kawalek, P. (2007). SMEs and IS innovations adoption: A review \& assessment of previous research, Accidentia Revista latinoamericana de Administration, $39, \quad 47-70$, URL: 
http://www.redalyc.org/articulo.oa?id=716 03904\# (Accessed on July 1, 2013)

Ramdani, B., Chevers, D. \& Williams, D.A. (2013). SMEs' adoption of enterprise applications. A technology-organisationenvironment model. Journal of Small Business and Enterprise Development, 20(4), 735-753.

Rao, S.S., Metts, G. \& Monge, C.A.M. (2003). Electronic commerce development in small and medium sized enterprises. Business Process Management Journal, 9(1), 11-32.

Rappa, M. (2001). Managing the Digital Enterprise - Business Models on the Web. URL: http://digitalenterprise.org/models /models.html, (Accessed on October 13, 2014)

Raymond, L. (2001). Determinants of Web Site Implementation in Small Business Internet Research. Electronic Network Applications and Policy, 11(5), 411- 422.

Riemenschneider, K. C, Harrison, A. D. \& Jr Mykytyn: P. (2003). Understanding IT adoption decisions in small business: Integrating current theories. Information \& Management, 40(4), 269285.

Ritchie, R. \& Brindley, C. (2000). Disintermediation, Disintegration and Risk in the SME Global Supply Chain. Management Decision, 38(8), 575-583.

Rodgers, J.A., Yen, D.C. \& Chou, D.C. (2002). Developing e-business: A strategic approach. Information Management \& Computer Security, 10, 184-192.

Rogers, E. M. (2003). Diffusion of innovation. 5th Edition. New York: The Free Press

Saffu, K. \& Walker, J. (2008). Strategic value and electronic commerce adoption among small and medium-sized enterprises in a transactional economy. Journal of Business\& Industrial Marketing, 23, 395404.

Saidoune, N. (2013). The development of electronic payment: The informal sector is the main obstacle. URL: http://zawaya. magharebia.com/old zawaya/en GB/ zawaya/opinion/211.html (Accessed on December 18, 2013)

Salwani, M. I., Marthandan, G., Norzaidi, M. D. \& Chong, S. C. (2009). E-Commerce usage and business performance in the
Malaysian tourism sector: Empirical analysis. Information Management \& Computer Security, 17(2), 166-185.

Schneider, F. (2012). The Shadow Economy and Work in the Shadow: What Do We (Not) Know? IZA Discussion Papers 6423, Institute for the Study of Labor (IZA). URL: http://papers.ssrn.com/sol3/papers.cfm?a bstract_id=2031951 (Accessed on January 12, 2014)

Schneider, F. \& Buehn, A. (2013). Shadow Economies in highly developed OECD countries: What are the driving forces? URL:http://www.business.otago.ac.nz/eco n/seminars/Abstracts/2013/Schneider24M ay.pdf. (Accessed on October 10, 2013)

Scupola, A. (2003). The adoption of internet commerce by SMEs in the South of Italy: An environmental, technological and organisational perspective. Journal of Global Information Technology Management, 6(1), 52- 71.

Shih, H. (2008). Contagion effects of electronic commerce diffusion: perspective from network analysis of industrial structure. Technological Forecasting \& Social Change, 75(1), 78-90.

Sigala, M. (2007). WEB 2.0 in the tourism industry: $A$ new tourism generation and new e-business models. URL: http://195. 130.87.21:8080/dspace/bitstream/123456 789/386/1/Web\%20\%20\%20in\%20the\%2 Otourism\%20industry\%20a\%20new\%20to urism $\% 20$ generation $\% 20$ and $\% 20$ new $\% 20$ e-business\%20models.pdf (Accessed on October 20, 2014)

Simmons, G., Armstrong, G. \& Durkin, M. (2008). A conceptualization of the determinants of small business website adoption: Setting the research agenda. International Small Business Journal 26(3), 351-389.

Simpson, M. \& Docherty, A. (2004). ECommerce Adoption Support and Advice for UK SMEs. Journal of Small Business and Enterprise Development, 11(13), 315328.

Smallbone, D. \& Welter, F. (2001). The Distinctiveness of Entrepreneurship in Transition Economies, Small Business Economics, 16, 249-262.

Soteriades, M., Aivalis, C. \& Varvaressos, S. (2004). E-Marketing and E-Commerce in 
the Tourism Industry: A Framework to Develop and Implement Business Initiatives. Tourism Today, 4, 157-169.

Sparling, L., Toleman, M. \& Cater-Steel, A. (2007). SME adoption of e-commerce in the central Okanagan region of Canada, Proceedings of the 18th Australasian Conference on Information Systems. URL: http://eprints.usq.edu.au/3598/1/Sparling Cater-Steel_Toleman.pdf (Accessed on January 20, 2014)

Stockdale, R. \& Standing, C. (2006). A classification model to support SME ecommerce adoption initiatives. Journal of Small Business and Enterprise Development, 13(3), 381-394.

Šumak, B., Pušnik, M. \& Heričko. (2012). Towards an E-Business Acceptance Model: Identification of External Factors. Proceeding of ITI $201234^{\text {th }}$ Conference on Information technology Interfaces, June 25-28, Cavtat, Croatia, 305-310.

Sun, H. \& Zhang, P. (2006). The role of moderating factors in user technology acceptance. International Journal of Human-Computer Studies, 64, 53-78.

Tan, J., Tyler, U. \& Manica, A. (2007). Business-to-business adoption of eCommerce in China. Information \& Management, 44, 332-351.

Tandon N. (2002). E-commerce Training with Small-Scale Entrepreneurs in Developing Countries: Some Findings. Presentation for UNCTAD E-Commerce Strategies for Development. URL: http://rO.unctad.org/ ecommerce/event_docs/estrategies/tando n.pdf (Accessed on May 10, 2014)

Taylor, M. \& Murphy, A. (2004). SMEs and ebusiness. Journal of Small Business and Enterprise Development, 11(3), 280-289.

Teo, T.S.H., Lin, S. \& Laib, K.-h. (2009). Adopters and non-adopters of eprocurement in Singapore: An empirical study. Omega, 37, 972-987.

Thomas, R., Shaw, G. \& Page, S. (2011). Understanding small firms in tourism: A perspective on research trends and challenges. Tourism Management, 32, 963-976.

Timmers, P. (1998). Business Models for electronic Markets, Electronic Markets, 8(2), 3-8.
To, M.L. \& Ngai, E.W.T. (2007). The role of managerial attitudes in the adoption of technological innovations: an application to B2C e-commerce. International Journal of Enterprise Information Systems, 3(2), 23-33.

Tornatzky, L.G. \& Fleischer, M. (1990). The Processes of Technological Innovation. Lexington, MA: Lexington Books.

Turban, E., King, D., Lee, J.K. \& Viehland, D. (2006). Electronic Commerce: A Managerial Perspective. Englewood Cliffs, NJ: Prentice-Hall.

Uzoka, F.M.E., Seleka, G.G. \& Shemi, A.P. (2007). Behavioural influences on ecommerce adoption in a developing country context. The Electronic Journal on Information Systems in Developing Countries, 31(4), 1-15.

Vateva, D. (2010). More than $25 \%$ of tour operators break the law. URL: from: http://www.dnevnik.bg/pazari/2010/08/23/ 950419_nad_25_ot_turoperatorite_narush avat zakona (Accessed on May 10, 2013)

Venkatesh, V. \& Davis, F.D. (2000). A theoretical extension of the technology acceptance model: four longitudinal field studies. Management Science, 46(2), 186204.

Venkatesh, V., Morris, M.G., Davis, G.B. \& Davis, F.D. (2003). User acceptance of information technology: toward a unified view. MIS Quarterly, 27(3), 425-478.

Visa Europe (2011). The Shadow Economy in Europe, 2011 - Using electronic payment systems to combat the shadow economy. Written by Friedrich Schneider and A.T. Kearney. URL: http://www.atkearney.de/ documents/856314/1214702/BIP_The_Sh adow_Economy_in_Europe.pdf/cd3277 da -74c3-4a35-9ac4-97f7a0e93518

(Accessed on January 11, 2014)

Visa Europe (2013). The Shadow Economy in Europe, 2013.URL: http://www.visaeurope .com/en/newsroom/news/articles/2013/sh adow_economy_report.aspx. (Accessed on September 3, 2013)

Vlachos, I.P. (2013). Investigating E-business practices in tourism: a comparative analysis of three countries. Tourismos: An International Multidisciplinary Journal of Tourism, 8(1), 179-198 
Vladimirov, Z. (2012). Customer satisfaction with the Bulgarian tour operators and travel agents' websites. Tourism Management Perspectives, 4, 176-184.

Vrana, V. \& Zafiropoulos, C. (2006). Tourism agents' attitudes on internet adoption: An analysis from Greece. International Journal of Contemporary Hospitality Management, 18(7), 601-608.

Wang, S. \& Cheung, W. (2004). E-Business Adoption by Travel Agencies: Prime Candidates for Mobile e-Business. International Journal of Electronic Commerce, 8(3), 43-63.

Wang, Y.-L., Wang, Y.-D. \& Horng, R.-Y. (2010). Learning and innovation in small and medium enterprises, Industrial Management \& Data Systems, 110(2), 175-192.

Wei, J., Platt, R., White, B. \& Jasquith, A.P. (2006). Development of Standardized ebusiness Solutions via e-chain Analysis in the Digital Utility. International Journal of Services and Standards, 2(2), 117-136.

Weill, P. \& Vitale, M. (2002). What IT infrastructure capabilities are needed to implement e-business models? MIS Quarterly Executive, 1(1), 17-34.

Welter, F., \& Smallbone, D. (2011). Institutional Perspectives on Entrepreneurial Behaviour in Challenging Environments. Journal of Small Business Management, 49(1), 107-125.

Wen, H.J., Lim, B. \& Huang, H.L. (2003). Measuring e-commerce efficiency: a data envelopment analysis (DEA) approach. Industrial Management \& Data Systems, 103(9), 703-710.

Werthner, H. \& Ricci, F. (2004). E-commerce and tourism. Magazine. Communications of the ACM - The Blogosphere CACM Homepage archive, 47(12), 101-105. URL: $\quad$ http://dl.acm.org/citation.cfm?doi $\mathrm{d}=1035134$. (Accessed on October 3, 2014)

Wilson, H., Daniel, E. \& Davies, I. A. (2008). The diffusion of e-commerce in UK SMEs. Journal of Marketing Management, 24(56), 489-516.

Wolcott, P., Kamal, M. \& Qureshi, S. (2008). Meeting the challenges of ICT adoption by micro-enterprises. Journal of Enterprise Information Management, 21(6), 616-632.
World Bank. (2013). Doing Business 2013: Smarter Regulations for Small and Medium-Size Enterprises. Washington, DC: World Bank Group.

WTO. (2001). E-Business for Tourism. Practical Guidelines for Tourism destinations and Businesses. URL:https://pub.unwto.org/WebRoot/Store /Shops/Infoshop/Products/1210/12101.pdf (Accessed on March 11, 2014)

WTTC (2011). Travel and Tourism 2011, URL: http://www.wttc.org/site_media/uploads/ downloads/traveltourism2011.pdf. (Accessed on August 20, 2013)

WTTC (2013). Travel and Tourism Economic Impact 2013. Bulgaria. URL: http://www.wttc.org/site_media/uploads/do wnloads/bulgaria2013.pdf. (Accessed on August 12, 2013)

Wu, F., Yeniyurt, S., Kim, D. \& Cavusgil, S.T. (2006). The impact of information technology on supply chain capabilities and firm performance: A resource-based view. Industrial Marketing Management, 35(4), 493-504.

Wynne, C., Berthon, P., Pitt, L., Ewing, M. \& Napoli, J. (2002). The impact of the internet on the distribution value chain: the case of the South African tourism industry. International Marketing Review, 18(4), 420-431.

Xheneti, M. \& Smallbone, D. (2008). The Role of Public Policy in Entrepreneurship Development in Post-Socialist Countries: A Comparison of Albania and Estonia, EBS Review, 24(1), 23-37.

Yaqub J. O., Bello H. T., Adenuga, I. A. \& Ogundeji, M. O. (2013). The Cashless Policy in Nigeria: Prospects and Challenges. International Journal of Humanities and Social Science, 3(3), 200-212.

Zhu, K. \& Kraemer, K.L. (2005). Post-adoption variations in usage and value of $e$ business by organizations: cross-country evidence from the retail industry. Information Systems Research, 16(1), 6184.

Zhu, L. \& Thatcher, S.M.B. (2010). National information ecology: a new institutional economics perspective on global ecommerce adoption. Journal of Electronic Commerce Research, 11(1), 53-71. 
Factors for the e-business adoption by small tourism firms and the role of shadow economic practices.
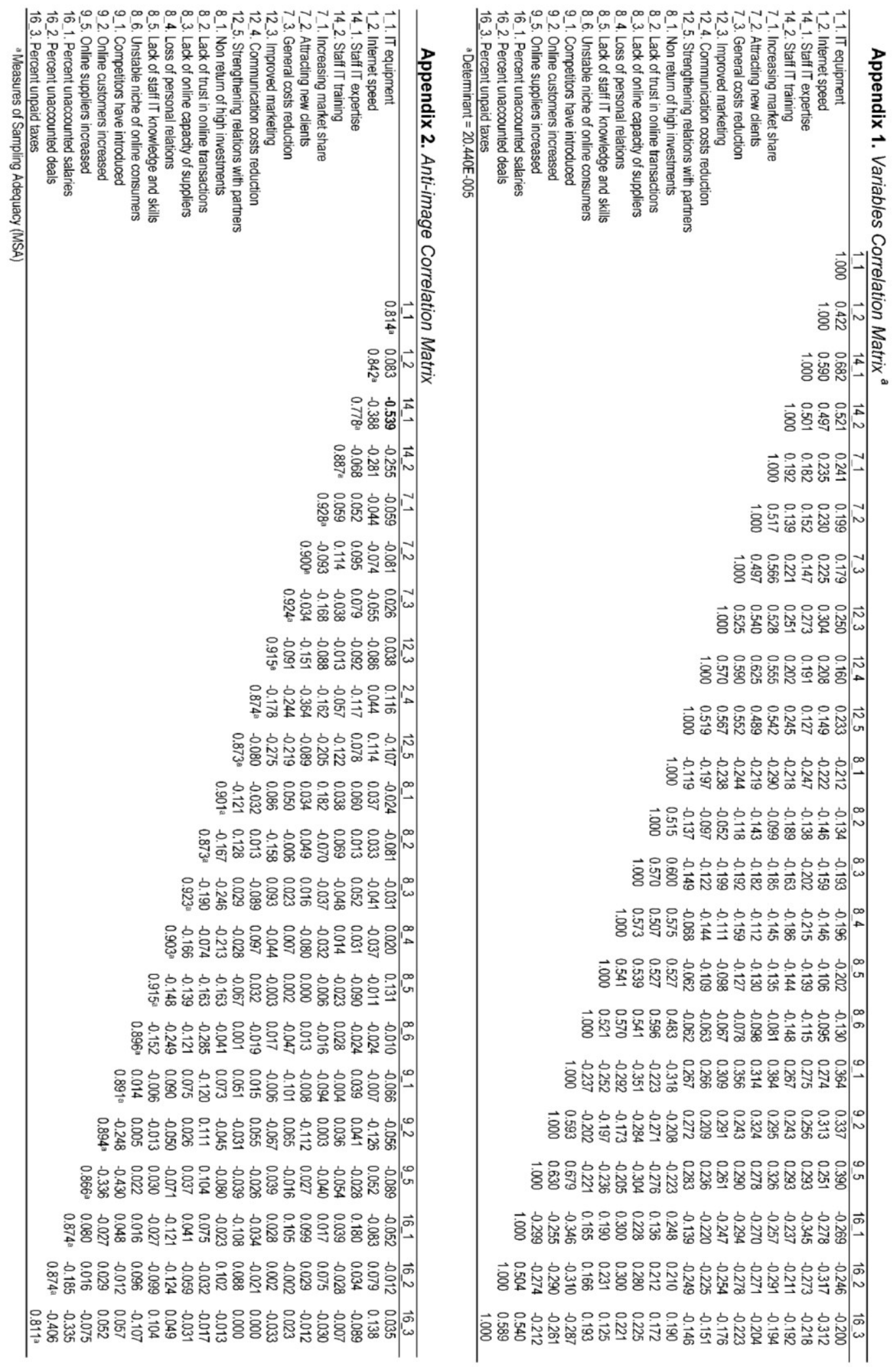
Appendix 3. Review of the research constructs, factors, and authors

\begin{tabular}{ll}
\hline Construct & Factors \\
\hline Technological & Perceived advantages and benefits: \\
context & Increasing market share; attracting new \\
& clients; general cost reduction; improved \\
& marketing; communication costs \\
& reduction; strengthening relations with \\
& partners.
\end{tabular}

\section{Authors}

General: Morrison and King (2002); Rogers (2003);

Gunasekaran and Ngai (2005); McKechnie et al.

(2006); Ifinedo (2011).

Specific: Poon and Swatman (1999); Baldwin et al. (2000); Raymond (2001); MacGregor and Vrazalic (2004); Grandon and Pearson (2004); Levy et al. (2005); Fillis and Wagner (2005); Hsu et al. (2006); Al-Qirim (2007); Saffu and Walker (2008); Simmons et al. (2008); Boateng and Heeks (2008); Teo et al. (2009); Chibelushi and Costello (2009); Kwun et al. (2010); Pham et al. (2011);

Perceived disadvantages and barriers: Non return of high investments; lack of trust in online transactions; lack of online capacity of suppliers; loss of personal relations; lack of staff IT knowledge and skills; unstable niche of online consumers.

Organisational readiness

Firm size and IT infrastructure:

Firm resources; level of IT equipment; internet speed

Human capital:

Staff IT expertise; and staff IT training

Industry environment

\section{Shadow economic practices}

\section{E-business} adoption
Competition and competitors' behaviour in respect to the e-business adoption; increased number of online suppliers; increased number of online customers

Percent unaccounted salaries; percent unaccounted deals; percent unpaid taxes

Availability of: online reservation system; online payment system; SCM and/or CRM; ERP system
Specific: Ritchie and Brindley (2001); Lawson et al. (2003); Riemenschneider et al. (2003); Simpson and Docherty (2004); Migiro and Ocholla (2005);

Galloway (2006); Stockdale and Standing (2006); Saffu and Walker (2008); Simmons et al. (2008); Johnson (2010); Kwun et al. (2010); Pham et al. (2011).

Firm size and IT infrastructure: Daniel et al. (2002);

Wang and Cheung (2004); Lucchetti and

Sterlacchini (2004); Lefebvre et al. (2005);

Stockdale and Standing (2006); Parker and Castleman (2007); Karakaya and Shea (2008); Lun and Quaddus (2011).

Human capital: O'Donnell et al. (2001); Caldeira and Ward (2002); Fabiani et al. (2005); Wolcott et al. (2008); To \& Ngai (2007); Eikebrokk and Olsen (2007); Jones et al. (2011)

Merhtens et al. (2001); Raymond (2001); Daniel et al. (2002); Baldwin et al. (2004); OECD (2004); Love et al. (2005); Levy et al. (2005); Wu et al. (2006); Jeon et al. (2006); Dinlersoz and Pereira (2007); Sparling et al. (2007); Lee and Kim (2007); BayoMoriones and Lera-López (2007); Niininen et al. (2007); Shih (2008); Ludivine (2009); Zhu and Thatcher (2010); Oliveira and Martins (2010). OECD (2004); Humphrey et al. (2003) ; Anderson et al. (2004); Kshetri (2010); Welter and Smallbone (2011); OECD (2012); Visa Europe et al. (2013); EU Parliament (2013)

Wang and Cheung (2004); Fillis and Wagner (2005); Hsu et al. (2006); Bayo-Moriones and Lera-López (2007); Pan and Jang (2008); Lin and Lin, 2008; Salwani et al. (2009); Bao and Sun (2010); Beckinsale et al. (2010), Chang et al. (2010); Oliveira and Martins (2010; 2011); Ghobakhloo et al. (2011), Cosgun and Dogerlioglu (2012), Peixin and Xie (2012), Abou-Shouk et al. (2013); Jabeur et al. (2013)

Caldeira and Ward (2002); To and Ngai (2007);

Eikebrokk and Olsen (2007) 
Factors for the e-business adoption by small tourism firms and the role of shadow economic practices.

Appendix 4. Demographic data of the interviewed managers

\begin{tabular}{|c|c|c|c|c|c|}
\hline Respondents & Type of company & Job position & $\begin{array}{l}\text { Edu } \\
\text { cation }\end{array}$ & Age & Gender \\
\hline $\mathrm{R} 1$ & Hotel & HR manager & High & 55 & $\mathrm{M}$ \\
\hline R2 & Travel agent & Manager & High & 30 & M \\
\hline R3 & Hotel & Administrator & High & 38 & $F$ \\
\hline R4 & Hotel & Manager & $\mathrm{Dr}$ & 40 & M \\
\hline R5 & Tour operator \& travel agent & $\begin{array}{l}\text { Manager } \\
\text { distribution }\end{array}$ & High & 40 & M \\
\hline R6 & Tour operator & Manager & High & 36 & M \\
\hline R7 & Tour operator \& travel agent & Manager & High & 31 & M \\
\hline R8 & Tour operator \& travel agent & Manager & High & 45 & M \\
\hline R9 & Travel agent & Manager & High & 50 & M \\
\hline R10 & Tour operator \& travel agent & Manager & High & 30 & $F$ \\
\hline R11 & Tour operator & Manager & High & 41 & M \\
\hline R12 & Hotel & Manager & High & 33 & $\mathrm{M}$ \\
\hline R13 & Tour operator \& travel agent & Manager & High & 35 & $\mathrm{~F}$ \\
\hline R14 & Tour operator \& travel agent & Manager & High & 38 & M \\
\hline R15 & Tour operator & Manager & High & 40 & M \\
\hline R16 & Tour operator & Manager & High & 31 & M \\
\hline $\mathrm{R} 17$ & Tour operator & Manager & High & 39 & $\mathrm{~F}$ \\
\hline R18 & Tour operator & Manager & High & 43 & $M$ \\
\hline R19 & Hotel & Sales manager & High & 51 & M \\
\hline R20 & Travel agent & Clients manager & High & 27 & $\mathrm{~F}$ \\
\hline $\mathrm{R} 21$ & Tour operator \& travel agent & Manager & High & 45 & M \\
\hline $\mathrm{R} 22$ & Tour operator \& travel agent & Manager contracts & High & 36 & M \\
\hline $\mathrm{R} 23$ & Tour operator & $\begin{array}{l}\text { Advertising } \\
\text { manager }\end{array}$ & High & 30 & M \\
\hline R24 & Hotel & Manager & High & 46 & $M$ \\
\hline $\mathrm{R} 25$ & Tour operator \& travel agent & Manager & High & 33 & $M$ \\
\hline R26 & Hotel & Administrator & $\mathrm{Dr}$ & 45 & $M$ \\
\hline $\mathrm{R} 27$ & Apart-hotel & Manager & High & 49 & M \\
\hline $\mathrm{R} 28$ & Tour operator \& travel agent & Manager & High & 35 & $M$ \\
\hline $\mathrm{R} 29$ & Hotel & Administrator & High & 33 & M \\
\hline $\mathrm{R} 30$ & Tour operator \& travel agent & Manager & High & 41 & $\mathrm{M}$ \\
\hline
\end{tabular}

